http://economix.fr

Exchange rate misalignments and the external balance under a pegged currency system 


\title{
Exchange rate misalignments and the external balance under a pegged currency system
}

\author{
Blaise Gnimassoun ${ }^{1}$
}

\begin{abstract}
This paper analyzes the link between the exchange rate misalignments and the external balance under a pegged currency system focusing on the CFA zone. Having discussed and chosen an appropriate analytical framework, it addresses the issue of model uncertainty regarding the equilibrium exchange rate model before estimating currency misalignments. The results show that misalignments have a negative and asymmetric impact on the current account. While overvaluation of the CFA franc deteriorates the current account in the CFA zone, undervaluation does not improve it. Finally, our results highlight that the export concentration tends to exacerbate the overall negative impact of currency misalignments on the external balance. Thus, greater economic diversification is needed in an environment in which countries face both uncertainty in the terms of trade and uncertainty in the nominal exchange rate to conduct a proactive exchange rate policy.
\end{abstract}

\section{JEL classification: F31, F32, C11.}

Keywords: Currency peg, Exchange rate misalignments, Current account, concentration of exports, Bayesian model averaging.

\section{Introduction}

It is a well-established fact that the real effective exchange rate is an important instrument of economic policy at both the national and the international level. If it can be used as an instrument of competitiveness for stimulating growth of non-traditional exports at the national level, particularly in developing countries, at the international level, it is the focus of discussions on the stability of the global economy, as we have recently seen in the worrying development of external imbalances (see Obstfeld and Rogoff, 2005; Bergsten, 2010; Goldstein, 2010). The line followed by the Washington Consensus is that the exchange rate in developing countries should remain sufficiently competitive to enable them to increase their exports and consequently strengthen their economies while ensuring that it is consistent with the potential production and sustainability of the external balance in those countries

\footnotetext{
${ }^{1}$ EconomiX-CNRS, University of Paris Ouest - Nanterre La Défense. E-mail address: blaise.gnimassoun@uparis10.fr
} 
(Williamson, 1990). Thus, if undervaluation seems beneficial for exports and growth, it should remain at a reasonable level so as not to shake the confidence of private investors due to inflationary pressures, which could hurt exports and growth. In other words, the Washington Consensus believes that the real exchange rate should remain at a level compatible with both the internal balance and the external one, known as the equilibrium exchange rate (Berg and Miao, 2010). Consequently, any distortion of exchange rates (or misalignments) - real overvaluation and real undervaluation - is harmful to the internal balance (economic growth) and the external balance (current account).

Researchers have frequently studied the consequences of misalignments for growth, paying little attention to their impact on the current account (Ghura and Grennes, 1993; Razin and Collins, 1997; Bleaney and Greenaway, 2001; Aguirre and Calderón, 2005; Rodrik, 2008; Berg and Miao, 2010; Gala, 2008; Béreau et al, 2012; Schröder, 2013; among others). The increase in external imbalances in developed countries, in particular in the euro area, made this question more attractive (Obstfeld and Rogoff, 2005; Belke and Dreger, 2013; Gnimassoun and Mignon, 2014). However, based on the definition of the equilibrium exchange rate, one can clearly deduce that exchange rate misalignments could be detrimental to the current account. Moreover, considering the logic of competitiveness, the current account is more directly exposed to currency misalignments and is the main channel through which they affect growth. On this basis, the study of the relationship between exchange misalignments and current account usefully complements those regarding the link between growth and misalignments that are far from unanimous. Indeed, while Schröder (2013) finds evidence in favor of the Washington Consensus by showing that undervaluation, like overvaluation, negatively affects economic growth for developing countries, Rodrick (2008) provides theoretical and empirical arguments showing that undervaluation is beneficial for developing countries. Berg and Miao (2010) lean towards Rodrick (2008) by showing that only overvaluation has negative consequences for growth and that undervaluation is beneficial. Supporting the thesis of Rodrick, Nouira et al. (2011) find that some developing countries have used a deliberate policy of undervaluation to strengthen the price competitiveness in their manufacturing sector. Other authors also emphasize a threshold effect in the relationship between exchange misalignments and growth suggesting therefore that the latter is nonlinear (Razin and Collins; 1997; Aguirre and Calderón, 2005; Béreau et al, 2012; Couharde and Sallenave, 2013).

This paper is part of the literature on the relationship between exchange rate misalignments and macroeconomic imbalances and focuses on the part of the story that has been little explored, namely the link between the exchange rate misalignments and the current account. It also focuses on the particular case of countries under a monetary union with an external nominal anchor-the countries of the CFA zone ${ }^{2}$ - for which a proactive policy of

\footnotetext{
${ }^{2}$ The CFA zone (acronym formerly designating "Colonies Françaises d'Afrique" and now "Communauté Financière Africaine") is comprised of fourteen countries: eight West African countries-Benin, Burkina Faso, Côte d'Ivoire, Guinea-Bissau, Mali, Niger, Senegal and Togo-forming the West African Economic and Monetary Union (WAEMU) and six Central African countries-Cameroon, the Central African Republic, the Republic of Congo, Gabon, Equatorial Guinea and Chad-forming the Central African Economic and Monetary Community (CAEMC). For the WAEMU, the CFA franc is now referred to as the franc of the "Communauté Financière d'Afrique" and the central bank is the BCEAO (Banque Centrale des Etats de l'Afrique de l'Ouest).
} 
undervaluation is unlikely. Indeed, in exchange for the relative macroeconomic stability (price, fiscal, FDI) offered to them by the peg to the euro (a more credible external currency), these countries have little leeway in price competitiveness, the evolution of which depends largely on the evolution of the anchor currency. This makes the issue of exchange misalignments more attractive for these countries to the extent that, being small open economies, they face double uncertainty: uncertainty related to changes in the terms of trade and uncertainty related to the evolution of the anchor currency. In both cases, these countries are considered "price takers."

Beyond the singular nature of this study, our paper contributes to the literature in several ways. First, our paper draws on the approach of the equilibrium exchange rate determined by economic fundamentals, the theoretical foundations of which were established by Edwards (1989). We go further than previous studies by deeply discussing the choice of this approach among others and paying special attention to the choice of fundamentals since the estimated equilibrium exchange rate is sensitive to this choice. Starting from the fundamentals suggested by Edwards (1989) and taking into account other fundamentals proposed in empirical studies on the CFA zone (Baffes et al., 1997; Devarajan, 1997; Roudet et al., 2007; Ouattara and Strobl, 2008; Mongardini and Rayner, 2009; Abdih and Tsangarides, 2010; Couharde et al., 2013), we address the issue of model uncertainty using model selection techniques. Specifically, we use two well-known econometric approaches-the Bayesian model averaging (BMA) approach and the general-to-specific (GETS) approach-usually used to address the same issue in growth models (Sala-I-Martin, 1997; Fernandez et al., 2001; Moral-Benito, 2012). These techniques have the advantage of allowing the identification of the fundamentals of the real exchange rate that are specific to the economies studied, avoiding the problem of parsimony that typically arises in empirical studies with a relatively large number of explanatory variables and limited data. Second, this paper provides a discussion on the macroeconomic and structural origins of exchange rate misalignments under a pegged exchange rate regime. Third, beyond the study of the link between misalignments and the current account, we attempt to verify whether the economic diversification mirrored by export diversification matters. Indeed, export diversification is supposed to limit the exposure of developing countries to external shocks, in particular shocks from terms of trade (Ghosh and Ostry, 1994; Hesse, 2009). For the countries of the CFA zone, which are also subject to potential shocks from the anchor currency, it seems important to study the influence of the concentration of exports.

Our findings show that the evolution of the real effective exchange rate in the CFA zone is mainly determined by the government consumption, terms of trade and relative productivity (Balassa-Samuelson effect). Studying the link between the current account and the exchange rate misalignments, we show that the misalignments of the CFA franc adversely affected the current account but asymmetrically. While the episodes of CFA franc overvaluation were significantly detrimental to the current account, the undervaluation episodes were not favorable for the current account. We also find that the negative impact of misalignments is

For the CAEMC, the CFA franc refers to the franc of the "Coopération Financière d'Afrique centrale" and the central bank is the BEAC (Banque des Etats de l'Afrique Central). All these countries are under a fixed exchange rate regime with France (and, since its creation, with the euro area). 
exacerbated by export concentration up to altering the potential positive impact of undervaluation into a real negative and significant impact.

The rest of the paper is organized as follows. Section 2 discusses the choice of the equilibrium exchange rate approach. In Section 3, we build the foundations of this approach through model selection techniques as well as econometric tests and estimates. Section 4 is devoted to the assessment and the explanation of exchange rate misalignments and their relationship with the current account. In section 5, we discuss the results and their policy implication. Finally, Section 6 concludes the paper.

\section{The choice of the equilibrium exchange rate approach for the CFA zone}

Depending on the time horizon to which they relate, several types of equilibrium exchange rates have been developed in the literature. ${ }^{3}$ For developing countries like those of the CFA zone, the purchasing power parity (PPP) approach is not relevant because it refers to the very long term and requires a full technological catch-up, which is not the case for those countries. Moreover, the application of the PPP model to countries in the CFA zone tends to conclude that the conditions of PPP are not fulfilled (Odedokun, 2000; Bahmani-Oskooee and Gelan, 2006). Thus, the choice often focuses on two very popular approaches with a shorter time horizon, namely the macroeconomic balance approach-also known as the fundamental equilibrium exchange rate approach-and the behavioral equilibrium exchange rate approach. ${ }^{4}$ To choose between the two approaches objectively, it is important to present their respective advantages and limitations as well as their suitability for the kind of country covered by this study.

The macroeconomic balance $(M B)$ approach or fundamental equilibrium exchange rate (FEER) approach. Developed by Williamson (1985), this approach is part of the mediumterm perspective and requires the achievement of internal balance and external balance simultaneously. The internal equilibrium occurs when the economy is at its potential level, a level at which unemployment is at its natural level (the non-accelerating inflation rate of unemployment, NAIRU). The external balance, for its part, supposes, from the internal point of view, that the rest of the world must also have achieved an internal balance. Indeed, if all the economies have an internal balance, then by definition the fundamental determinants of the exchange rate are at their medium-term setting (see Driver and Westaway, 2005). However, the external balance does not necessarily imply that all current accounts will be equal to zero, as there is no reason why in the medium term savings have to equal investment in all economies. The external balance is rather consistent with a "sustainable" level of the current account. Thus, this approach is also often referred to as the external sustainability approach, especially when the sustainable level of the current account is considered as the one that stabilizes the "normative" net foreign asset (NFA) position.

\footnotetext{
${ }^{3}$ For further details on the different equilibrium exchange rate concepts and the array of acronyms that have been proposed in the economics literature, see for example Driver and Westaway (2005).

${ }^{4} \mathrm{We}$ consider here the approaches of real exchange rates that move beyond the nominal exchange rates determined on the exchange markets by the confrontation between supply and demand for currencies and that are supposed to reflect their equilibrium values continuously.
} 
The behavioral equilibrium exchange rate (BEER) approach. Although this approach is associated with the work of Faruqee (1995), MacDonald (1997) and Clark and MacDonald (1998), a similar development was proposed by Edwards $(1988,1989)$ in his study on the exchange rate misalignments in developing countries. The BEER is based on the principle that changes in the exchange rate are driven by a number of internal and external economic fundamentals. From this point of view, the BEER approach appears to be an econometric approach and the equilibrium exchange rate is the one estimated from fundamentals when these are at their structural level. As we show below, the literature provides an overview of the fundamentals generally considered.

Which approach to choose? These two approaches have their advantages and disadvantages. For example, although the BEER approach has the advantage of being simple, it is often criticized for having no clear theoretical foundation and being sensitive to the choice of the fundamentals and the econometric approach. Although the FEER approach, meanwhile, has a macroeconomic basis, it is often criticized for its sensitivity to import and export exchange rate elasticities, as well as the choice of benchmarks for the current account. In general, for developing countries, like those covered by this study, the BEER approach appears (under certain conditions including that related to the choice of the "true" fundamentals) to be the most suitable for several reasons.

First, the rapid evolution of economic fundamentals in these countries makes a normative approach such as the FEER hardly appropriate. For example, the average economic growth of the CFA zone was $1.8 \%$ during the 1980 s and $3.1 \%$ in the 1990 s, reaching $4.3 \%$ during the 2000s. Moreover, while trade between the CFA and China accounted for less than $2 \%$ of the total trade of the CFA zone in 1995, it rose to almost $14 \%$ in $2012 .{ }^{5}$ It therefore appears to be difficult to define the internal and external balances that underlie the FEER approach in these conditions. Thus, it seems to be more appropriate to consider an approach like the BEER, which is able to capture such changes in fundamentals. This also allows us to estimate a progressive equilibrium exchange rate and to conduct a dynamic analysis of the development of exchange rate distortions.

Second, misalignments estimated following the FEER approach are more likely to be biased in the context of developing countries. Indeed, the estimation of exchange rate misalignments following the FEER approach is subject to a set of parameters of which the accuracy for developing countries may be questionable. The underlying current account required in this approach is calculated with respect to the potential production. The weight of the informal sector in these countries complicates the measurement of this level of production. Moreover, data on the potential GDP of developing countries are not available. In addition, the elasticities of exports and imports relative to the real effective exchange rate are often chosen arbitrarily (see Aydin, 2010). When the current account norm is given, it may be deemed arbitrary, and when it is estimated, it is subject to the same criticisms as the BEER. In other words, the estimation of the misalignments by the FEER approach assumes several phases of uncertainty (elasticities of exports and imports relative to the real effective exchange rate,

\footnotetext{
${ }^{5}$ These elements are derived from the UNCTAD and IMF databases.
} 
level of potential output, sustainable current account) that increase the risk of inaccuracy in measuring misalignments (see Devarajan, 1997).

These elements show that the implementation of the FEER approach for developing countries generally leads to the use of econometric tools therefore making outdated its comparative advantage compared to the BEER approach (see e.g. Abdih and Tsangarides (2010) for the case of the CFA area). In these circumstances, the choice of the BEER approach seems to be more fitting, especially when the fundamentals are economically justified, as in Edwards (1989). ${ }^{6}$ Thus, the fundamentals-based approach is generally used more often in empirical studies to estimate exchange rate misalignments in developing countries (Zhang, 2001; Candelon et al., 2007; Nouira et al., 2011; Schröder, 2013). However, beyond their economic foundation, it is also important to ensure that the fundamentals selected are the most relevant drivers of the exchange rate for the countries that are the subject of the study, which previous studies in general fail to do. Furthermore, it seems necessary to rely on robust econometric methods to estimate the BEER approach. It is these provisions that enhance the BEER that we set up in the following sections.

\section{The foundations of the behavioral equilibrium exchange rate model in the CFA zone}

Estimating the behavioral equilibrium exchange rate requires us to build an exchange rate model that contains the "true" fundamentals of the real effective exchange rate. The previous empirical and theoretical literature is very useful in this respect. However, this literature does not allow research to be totally free from mistaken judgments on the choice of fundamentals because these can differ depending on the study and the countries concerned. In addition, it is unlikely, through a single theoretical model, that a study can fully analyze all the empirical relationships between the real effective exchange rate and its potential fundamentals. Empirical studies are usually conducted in the context of a lack of clear theoretical orientation and most of them make an arbitrary choice of the model specification. This a priori choice is subject to potential bias given the very large number of possible specifications that are ignored. Moreover, the lack or limited availability of data for developing countries increases the inefficiency of an empirical model with several explanatory variables. All this gives rise to what is considered in the literature as model uncertainty. It is therefore important to adopt an efficient strategy that combines the relevance of the explanatory variables and the robustness of the estimation.

\subsection{The data and the issue of model uncertainty}

We rely on the fundamentals put forward by the previous theoretical and empirical studies. Specifically, we draw on Edwards (1989), ${ }^{7}$ who identifies external fundamentals (international terms of trade, international transfers and world real interest rates) and domestic fundamentals (trade barriers, capital controls, government expenditure and technological

\footnotetext{
${ }^{6}$ Similar approaches are proposed by Elbadawi (1994) and Baffes et al. (1999).

7 The emphasis is on the model of Edwards (1989) because it lays the theoretical foundations of the fundamentals of the real exchange rate for developing countries. See the author for more explanations of how these variables affect the dynamics of the real exchange rate.
} 
progress) for developing countries. Empirical applications have expanded the field of these fundamentals. Indeed, international transfers are usually associated with official development assistance and migrants' remittances (see Ouattara and Strobl, 2008; Mongardini and Rayner, 2009). For the CFA zone countries, other studies highlight the potential influence of investment on the dynamics of the real effective exchange rate (see e.g. Baffes et al., 1997; Roudet et al., 2007; Abdih and Tsangarides, 2010). The net foreign assets are also often referred to as one of the major determinants of the real effective exchange rate (Couharde et al., 2013; Coulibaly and Gnimassoun, 2013).

Based on this literature, we establish a list of 12 potential internal and external macroeconomic determinants of the real effective exchange rate in the CFA zone. ${ }^{8}$ Under the domestic fundamentals, we group government expenditures (gov), money supply ( $m 2)$ and investment (invest), all three expressed as a percentage of the GDP, relative productivity measured by the level of PPP-adjusted GDP per capita $(p r o d)^{9}$ to capture the BalassaSamuelson effect, the degree of trade openness (topen) measured by the sum of exports and imports to the GDP, used as a proxy for trade barriers, and a capital control measure (kacont) obtained from the Chinn and Ito (2006) database. Concerning the external fundamentals, we consider foreign direct investment $(f d i)$, net foreign assets $(n f a)$, official development assistance (oda), and migrants' remittances (rem), all expressed as a percentage of the GDP, terms of trade (tot) and the world real interest rate (wrir).

The data initially mobilized for all of these variables are annual, spanning the period from 1980 to 2012 for a panel of 12 CFA zone countries. ${ }^{10}$ Then we construct non-overlapping 4year averaged data ${ }^{11}$ allowing to smooth business-cycle fluctuations and therefore really focus on the underlying determinants of real effective exchange rate as is done in the context of current account models (see among others, Chinn and Prasad, 2003; Lane and Milesi-Ferretti, 2012; Gnimassoun, 2015) or cross-country growth literature (see for example Ding and Knight, 2011). This is particularly relevant for developing countries like those of the CFA zone for which measurement errors are also at stake, in addition to significant short-term fluctuations they face due to the volatility of commodity prices (Barro, 1991; Bleaney and Greenaway, 2001).

To address concerns about model uncertainty and identify the key determinants (fundamentals) of the real effective exchange rate in the CFA zone, we first use Bayesian model averaging (BMA). By estimating all possible models from all combinations of the explanatory variables, this technique allows to determine the posterior inclusion probability associated with each variable (for more details, see Appendix B.1). Table 1 presents a summary of the BMA results, where the posterior inclusion probability (PIP BMA), the posterior mean (Post Mean), the standard posterior deviation (Post SD) and the "posterior

\footnotetext{
${ }^{8}$ Data sources for each series are presented in Table A.2 in Appendix.

${ }^{9}$ This variable is considered as a proxy for technological progress (see Abdih and Tsangarides, 2010), allowing the model to be in line with that of Edwards (1988).

${ }^{10}$ The CFA zone consists of 14 countries but for reasons of data availability for Guinea-Bissau and Equatorial Guinea, both countries are not included in our sample.

${ }^{11}$ Note that 4-year averaged data are used only in the context of model-selection. In the remainder of the paper, we consider the annual data to account for short term dynamics of the real effective exchange rate; which is crucial in the analysis of misalignments.
} 
probability of a positive coefficient expected value conditional on inclusion", respectively "sign certainty" (Cond.Pos. Sign) ${ }^{12}$ for each variable are reported. To interpret these results, we mainly focus on the posterior inclusion probability for each variable that is the sum of posterior model probabilities for all models in which each variable appears. By choosing a uniform prior probability, as is often the case, each variable has a priori probability of 0.5 to be in the true model. We therefore consider to a specific variable as being important if its PIP is greater than 0.5 . The results thus show that government consumption, relative productivity and the terms of trade can be considered as the fundamentals of the real effective exchange rate in the CFA zone.

Table 1: Bayesian model averaging (BMA) results

\begin{tabular}{|c|c|c|c|c|}
\hline $\begin{array}{l}\text { REER } \\
\text { Fundamentals }\end{array}$ & BMA PIP & Post Mean & Post SD & Cond.Pos. Sign \\
\hline \multicolumn{5}{|l|}{ Internal } \\
\hline gov & 0.871 & 0.864 & 0.455 & 1.000 \\
\hline invest & 0.095 & -0.015 & 0.107 & 0.040 \\
\hline$m 2$ & 0.093 & -0.014 & 0.124 & 0.045 \\
\hline kacont & 0.192 & -0.060 & 0.161 & 0.000 \\
\hline prod & 0.987 & 0.181 & 0.052 & 1.000 \\
\hline topen & 0.146 & -0.018 & 0.062 & 0.003 \\
\hline \multicolumn{5}{|l|}{ External } \\
\hline$f d i$ & 0.088 & 0.006 & 0.225 & 0.493 \\
\hline nfa & 0.088 & -0.001 & 0.017 & 0.542 \\
\hline oda & 0.107 & 0.036 & 0.202 & 0.972 \\
\hline rem & 0.149 & 0.179 & 0.603 & 0.993 \\
\hline tot & 1.000 & 0.348 & 0.054 & 1.000 \\
\hline wrir & 0.083 & -0.110 & 0.994 & 0.080 \\
\hline
\end{tabular}

Note: Estimation is based on 4-year averaged data; dependent variable: real effective exchange rate.

The results are based on 500,000 draws and 100,000 burn-ins. For each simulation, we use a uniform model prior and the birth-death MCMC sampler. Statistics in bold are those whose posterior inclusion probability is greater than or equal to $50 \%$. The correlation between iteration counts and analytical posterior model probabilities for the 2000 best models is 0.9918 .

To strengthen our results, we then use the automated General-to-specific (GETS) approach ${ }^{13}$ as an alternative approach to BMA to deal with model uncertainty. Indeed, GETS, just as BMA, is one of the most influential econometric and statistical approaches for handling uncertainty modelling (see Ding and Knight, 2011). Roughly speaking, while BMA addresses model uncertainty by estimating models for all possible combinations of explanatory variables leading to thousands (or millions) of regressions, the GETS addresses the same problem relying on a single model, namely the general unrestricted model (GUM). The latter, which contains all the potential explanatory variables, is subjected to a series of step-wise statistical tests (see Hendry and Krolzig, 2004), leading to the removal of empirically unimportant variables to arrive at the proposed specific or final model. Table 2 reports the OLS estimation of the specific (or final) model. These results confirm the results from the

\footnotetext{
${ }^{12}$ When the statistic is close to 1 , the variable has undoubtedly a positive sign, while when it is close to zero, the variable has a negative sign.

${ }^{13}$ This approach is briefly discussed here. For details, see among others Krolzig and Hendry (2004), Hoover and Perez (2004), and, for a practical implementation, see Owen (2003) for the OxMetrics software and Clarke (2011) for the Sata software.
} 
BMA approach insofar as the variables occurring in the specific model are those for which the PIP is greater than $50 \%$ in the BMA results. On the whole, government consumption, terms of trade and relative productivity are found to be robust determinants of the real effective exchange rate of the CFA zone, in line with most previous studies (Abdih and Tsangarides, 2010; Couharde et al. 2013; Coulibaly and Gnimassoun, 2013). Figure 1 shows the posterior coefficient densities and is convincing on the positive sign associated with each of the fundamentals of the real effective exchange rate. So we should logically find the same results when estimating our BEER model. The interest of this figure is that it removes any doubt about the sign associated to fundamentals showing their empirical distribution. For example, theoretically, the sign associated with government consumption may be positive or negative depending on its composition in tradable and non-tradable goods. Figure 1 indicates that there is no ambiguity about the fact that an increase in government consumption leads to an appreciation of the real exchange rate showing that government consumption is biased in favor of non-tradable goods; which is often observed in empirical studies (Edwards, 1989; Schröder, 2013).

Table 2: General-to-specific (GETS) results

\begin{tabular}{|c|c|c|c|c|}
\hline $\begin{array}{l}\text { REER } \\
\text { Fundamentals }\end{array}$ & Coef. & Std. Err. & T-stat. & $P>|t|$ \\
\hline gov & 0.778 & 0.264 & 2.950 & 0.004 \\
\hline prod & 0.193 & 0.045 & 4.310 & 0.000 \\
\hline tot & 0.338 & 0.051 & 6.630 & 0.000 \\
\hline cons & 0.370 & 0.085 & 4.340 & 0.000 \\
\hline Obs. & 96 & & $F(3,92)$ & 39.19 \\
\hline$R 2$ & 0.56 & & $A I C$ & -13.953 \\
\hline
\end{tabular}

Note: This is the OLS estimation of the final specific model based on 4-year averaged data; dependent variable: real effective exchange rate. F (3, 92): joint significant test and AIC: Akaike's information criterion.

\subsection{Econometric tests and estimation of the BEER}

The results of model-selection techniques allow us henceforth to specify our "benchmark REER model" to estimate the BEER as follows:

$$
\ln \left(\text { reer }_{i, t}\right)=\alpha_{i}+\varphi_{i} t+\theta_{t}+\beta_{1} \ln \left(\operatorname{gov}_{i, t}\right)+\beta_{2} \ln \left(\operatorname{prod}_{i, t}\right)+\beta_{3} \ln \left(\text { tot }_{i, t}\right)+\varepsilon_{i, t}
$$

where $i(i=1, \ldots, N)$ denotes the country, $t(t=1, \ldots, T)$ the time and $\varepsilon_{i, t}$ is a vector of errors. This equation accounts for country specific effects $\left(\alpha_{i}\right)$, heterogeneous linear trends $\left(\varphi_{i} t\right)$ and common time effects $\left(\theta_{t}\right)$ allowing for some degree of cross-section dependence (see Mark and Sul, 2003). All variables of the model are expressed in logarithms (ln). The estimate of the BEER (or the relationship of cointegration between the real effective exchange rate and its fundamentals) is subject to two main econometric tests: unit root tests and cointegration tests to establish that there actually a long-term relationship. To do this, we mobilize the most appropriate tests as part of panel data to take into account the cross- 
sectional dependencies and possible structural breaks. ${ }^{14}$ For unit root tests, we use the test developed by Carrion-i-Silvestre et al. (2005) which allows for the presence of multiple unknown structural breaks under the null hypothesis of stationarity and does not impose cross-section independence in the error terms through bootstrapping. The results of this test show that the null hypothesis of stationarity is strongly rejected for all series (Table 3, (a)). Consequently, we test for the existence of a cointegration relationship between these series by relying on Westerlund (2007)'s panel cointegration test. This test relies on an error-correction model and tests the significance of the error-correction coefficient. It also accounts for the cross section dependence between countries through bootstrapping. The results of this test (Table 3, (b)) support the existence of a cointegrating relationship between the real effective exchange rate and its fundamentals regardless of the assumption on the cointegrating vector (homogeneous cointegrating vectors (statistics $P_{t}$ and $P_{a}$ ) or heterogeneous cointegrating vectors (statistics $G_{t}$ and $G_{a}$ ). Finally we estimate this cointegration relationship using the Panel Dynamic OLS (Panel DOLS) method developed by Mark and Sul (2003). This method consists in augmenting the cointegrating relationship with leads and lags of the first difference of the explanatory variables to control for the endogenous feedback effect. The results of the regression are consistent with the model-selection (BMA and GETS) results insofar as the estimated coefficients are statistically significant at the $1 \%$ and have the expected signs. These results are also similar to those of previous studies. For example, Couharde et al. (2013) find for the same area an estimated coefficient of 0.36 for $\ln ($ prod $), 0.22$ for $\ln (t o t)$ and 0.42 for $\ln (g o v)$ knowing that they include in their regression a fourth variable $(n f a)$, which is moreover not significant. For Sub-Saharan Africa, Elbadawi et al. (2012) find a coefficient of 0.55 for $\ln ($ prod $), 0.20$ for $\ln ($ tot $)$ and 2.63 for $\ln ($ gov $)$ using Pooled mean group (PMG) estimator.

Economically, the positive sign associated with relative productivity in our study, as in others, is evidence of the existence of the Balassa Samuelson effect which states that an increase in relative productivity between tradable and non-tradable goods leads to an appreciation of the real equilibrium exchange rate. Moreover an improvement in terms of trade leads to an appreciation of the real equilibrium exchange rate. Finally, to the extent that government consumption in the CFA zone as in most developing countries is generally more geared towards non-tradable goods, an increase in government consumption leads to an appreciation of the real equilibrium exchange rate.

\footnotetext{
${ }^{14}$ For further details on these tests, see Gnimassoun and Coulibaly (2014).
} 
Table 3: Econometric tests and estimation results

\begin{tabular}{|c|c|c|c|c|c|c|c|c|}
\hline \multirow{2}{*}{\multicolumn{3}{|c|}{$\begin{array}{c}\text { (a) } \\
\text { Carrion et al. (2005)'s Panel } \\
\text { Unit Root Test }\end{array}$}} & \multirow{2}{*}{\multicolumn{3}{|c|}{$\begin{array}{c}\text { (b) } \\
\text { Westerlund (2007)'s Panel } \\
\text { cointegration tests }\end{array}$}} & \multicolumn{3}{|c|}{ (c) } \\
\hline & & & & & & $\begin{array}{r}\text { Mark an } \\
\text { DOLS }\end{array}$ & $\begin{array}{l}\text { Sul (200 } \\
\text { stimatic }\end{array}$ & $\begin{array}{l}\text { s Panel } \\
\text { results }\end{array}$ \\
\hline \multirow{2}{*}{ Variables } & \multicolumn{2}{|c|}{ Long-run variance } & \multirow{2}{*}{ Statistic } & \multirow{2}{*}{ Value } & \multirow{2}{*}{$\begin{array}{c}\text { Robust P- } \\
\text { Value }\end{array}$} & \multirow{2}{*}{ Variables } & \multicolumn{2}{|c|}{$\operatorname{Ln}($ reer $)$} \\
\hline & Homo & Hetero & & & & & Coeff. & T-Stat. \\
\hline $\ln ($ reer $)$ & $4.67 * * *$ & $26.82 * * *$ & $G_{t}$ & -2.50 & 0.00 & & & \\
\hline $\ln (g o v)$ & $4.81^{* * *}$ & $8.38^{* * *}$ & $G_{a}$ & -6.45 & 0.04 & $\ln ($ gov $)$ & $0.69 * * *$ & 13.618 \\
\hline $\ln ($ prod $)$ & $13.91 * * *$ & $12.18 * * *$ & $P_{t}$ & -7.68 & 0.02 & $\ln ($ prod $)$ & $0.39 * * *$ & 6.904 \\
\hline $\ln (t o t)$ & $5.96^{* * * *}$ & $14.29 * * *$ & $P_{a}$ & -5.42 & 0.04 & $\ln ($ tot $)$ & $0.18 * * *$ & 3.483 \\
\hline
\end{tabular}

Notes: (a) $* * *, * *, *$ indicate the rejection of the null hypothesis of stationarity at the $1 \%, 5 \%$ and $10 \%$ significance levels respectively. The optimum break point is chosen by considering the modified Schwarz information criterion (LWZ). We consider a model with constant and trend.

(b) Only bootstrap P-Values are reported. Robust P-Value $<5 \%$ means that the null hypothesis of no cointegration is rejected. The Bartlett kernel window width is set according to $4(T / 100)^{2 / 9} \approx 3$.

(c) $* * *, * *, *$ indicate that the coefficient is respectively significant at $1 \%, 5 \%$ and $10 \%$ levels.

\section{The empirical relationship between the current account and the misalignments}

This section proposes a discussion of the misalignments of the CFA before analyzing their impact on the current accounts of the CFA zone countries. The first part offers a standard assessment of the CFA franc misalignments and discusses their sources in light of the exchange rate regime. The second part analyzes the influence of the misalignments on current accounts and the third part examines the role of the concentration of exports in this relationship.

\subsection{The CFA franc misalignments: between macroeconomic-induced and structural factors}

Exchange rate misalignments are commonly defined as the difference between the real effective exchange rate and its equilibrium level. It is precisely this equilibrium exchange rate level that is given by the BEER, so misalignments (mis) are valued as follows:

$$
\begin{gathered}
\operatorname{mis}_{i, t}=\ln \left(\text { reer }_{i, t}\right)-\ln \left(\text { beer }_{i, t}\right) \\
=\ln \left(\text { reer }_{i, t}\right)-\left[0.69 \ln \left(\widetilde{\text { gov }_{i, t}}\right)+0.39 \ln \left(\widetilde{\text { prod }}_{i, t}\right)+0.18 \ln \left(\widetilde{\text { tot }}_{i, t}\right)\right]
\end{gathered}
$$

\footnotetext{
15 Note that cross-section dependences have been accounted for in the DOLS estimation of the long-term, cointegrating relationship. As a robustness check, we have also used the PMG approach introduced by Pesaran et al. (1999) which allows the short-run coefficients to differ freely across countries while the long-run coefficients are restricted to be the same for all individuals. The estimated parameters are very close to those with DOLS approach with an estimated coefficient of 0.63 for $\ln (\mathrm{gov}), 0.38$ for $\ln ($ prod) and 0.26 for $\ln ($ tot $)$ all statistically significant at $1 \%$ except $\ln ($ prod) which is significant at $10 \%$.
} 
where $\widetilde{g o v}_{i, t}, \widetilde{\operatorname{prod}}_{i, t}$ and $\widetilde{t o t}_{i, t}$ are the sustainable values of the fundamentals (respectively government consumption, relative productivity and terms of trade). Like Schröder (2013), we use the Hodrick-Prescott (HP) filter, which is one of the conventional techniques to decompose series into cyclical and trend components. The trend component is considered as the sustainable component of the series.

Having defined misalignments, an interesting question that comes to mind is that concerning the cause of these monetary distortions. The literature provides a fairly general answer to this question. Indeed, the exchange rate regime appears to be one of the most important determinants of misalignments (see among others Stockman, 1999; Coudert and Couharde, 2009; Dubas, 2009). Edwards (1989) defines two types of misalignments: macroeconomicinduced misalignments and structural misalignments. The first comes from inconsistencies between macroeconomic policies (especially monetary ones) and the official exchange rate system so that the real effective exchange rate deviates from its equilibrium value. The second is due to short-term imbalances in the fundamentals of the real effective exchange rate. A typical example is that of a shock to the terms of trade that influences the real equilibrium exchange rate and leads to misalignments when the observed real effective exchange rate does not change. For the CFA zone countries, the macroeconomic distortions (and especially the monetary ones) may stem from the fact that the evolution of the anchor currency causes a deviation of the real effective exchange rate (of the CFA zone) from its equilibrium value. It is even more likely that the evolution of the anchor currency does not necessarily reflect the changes in the fundamentals of these countries and that neither the country nor the union as a whole can influence the evolution of the anchor (which is the strict responsibility of the European Central Bank). Indeed, although the central banks in the CFA zone are primarily responsible for price stability, they have no leeway in the evolution of the nominal effective exchange rate, which is mainly determined by the evolution of the anchor currency. Table A.3 in the appendix shows how the anchor currency - the French franc ${ }^{16}$ - influences the CFA franc. It is clear that any change in the nominal effective exchange rate of the anchor currency results in a relatively equivalent effective nominal change in the CFA franc. This nominal variation of the anchor seems also explained $90 \%$ of real effective variation of the CFA franc, hence the importance of the change in the anchor currency on the price competitiveness in the CFA zone. This is not problematic if the intra-regional trade is dominant or if France is the largest trading partner to the extent that currency risks are less important. But with its expansion, China has become the first commercial partner in several countries of the CFA zone as Benin, Chad and Togo and the intra-zone trade remains low (around 10\%). However, the misalignments of the CFA franc are not only determined by the evolution of the anchor currency as their magnitude also depends on the equilibrium exchange rate that is itself determined by economic fundamentals that are specific to the CFA zone. Thus, there are margins of maneuver for competitiveness in the CFA zone but they are rather structural (based on economic structures and not on the price).

\footnotetext{
${ }^{16}$ Despite the changeover to the euro since 1999, the French franc can still be considered as the nominal anchor of the CFA franc to the extent that parity between the two currencies has not changed and that the French franc arithmetically represents a fixed proportion of the euro.
} 
Consequently, by following Edwards (1989), the monetary distortions in the CFA zone arise from changes in the nominal effective exchange rate due to changes in the anchor currency resulting in a deviation of the real effective exchange rates from their equilibrium levels. As this situation cannot last indefinitely, it usually results in devaluation or revaluation of the currency. Regarding the structural misalignments of the CFA zone, they would be the consequence of deviations of the fundamentals from their structural value.

\subsection{How do misalignments affect the current account in the CFA zone?}

Having estimated and explained the misalignments in the CFA zone, we focus now on the effects of these misalignments on the current account. Indeed, although the literature focuses mostly on the impact of misalignments on growth, one of the most important channels through which these misalignments affect the growth is that of external competitiveness. This external competitiveness is primarily linked with the external balance. Currency undervaluation is commonly regarded as beneficial to the tradable sector and therefore favorable to growth, especially when this sector makes an important contribution to the economy's overall growth (Rodrik, 2008). However, overvaluation represents losses of external competitiveness and is therefore detrimental to growth. If the impact of misalignments appears to be twofold, the overall effect of misalignments on growth is rather negative (Ghura and Grennes, 1993; Schröder, 2013). For example, some studies show that overvaluation is more harmful to growth than undervaluation of the same magnitude is beneficial for growth (Aguirre and Calderón, 2005).

To study the relationship between the current account and the exchange rate misalignments, we estimate a current account model by introducing misalignments (mis) as the variable of interest. The estimated current account model is specified as follows:

$$
c a_{i, t}=a_{i}+b m i s_{i, t}+\sum_{J=1}^{n} c_{j} z_{i, t}+\mu_{i, t}
$$

with $n$ denoting the number of explanatory control variables $z_{i, t}, \mu_{i, t}$ being an i.i.d. error term, and $a_{i}$ standing for country-fixed effects.

Having specified the equation, it seems to be important to draw attention to what can lead to confusion in the interpretation of results. Indeed, under the assumption that any exchange rate distortion is harmful (the view of the Washington Consensus), we expect a negative relationship between the misalignments and the current account, as is often the case with economic growth. The general spirit behind this link is that the external balance will be even more improved when the misalignments are low $\left(m i s_{i, t}=0\right)$. However, since a positive (negative) sign associated with misalignment means overvaluation (undervaluation) of the exchange rate, a negative sign between the misalignments and the current account also suggests that overvaluation would degrade the current account while undervaluation would improve the current account symmetrically. The latter interpretation implies that the undervalued and overvalued exchange rates have equal and opposing effects on the current account. To account for the possible effect of asymmetric misalignments, the latter are split into two series: a series of undervaluation (under) taking the negative values of misalignments and zero otherwise and a series of overvaluation (over) taking the positive values of 
misalignments and zero otherwise. A negative coefficient associated with both variables supports the hypothesis that an undervalued (overvalued) exchange rate promotes (deteriorates) the current account.

For the control variables, we follow the literature on the medium-term determinants of current accounts (Chinn and Prasad, 2003; Ca'Zorzi et al., 2012; Lane and Milesi-Ferretti, 2012) by considering various traditional explanatory variables, namely: ${ }^{17}$ (i) the relative fiscal balance (fis) expressed as a ratio to GDP, (ii) the lagged net foreign asset position ( $n f a$ ) expressed as percentage of GDP, (iii) the relative level of PPP-adjusted GDP per capita (prod) ${ }^{18}$, (iv) the relative GDP growth rate ( $r g r w)$, (v) the relative old-age dependency ratio (ro) defined as the ratio of the population aged 65 and older to the working-age population, (vi) the relative young-age dependency ratio ( $r y$ ) defined as the ratio of the population younger than 15 to the working-age population, (vii) the relative population growth rate (rpopg), (viii) a proxy of financial deepening (fint) given by the sum of total assets and liabilities to GDP ratio, (ix) the degree of openness (open) given by the ratio of exports plus imports of goods and services to GDP, (x) terms of trade (tot), and (xi) the oil balance (oilb) expressed as percentage of GDP. Data sources for each series are presented in Table A.2 in Appendix. All variables but $n f a$, fint, open, tot and oilb are expressed in relative terms, since only idiosyncratic shifts in fundamentals should affect the current account (see Lane and Milesi-Ferretti, 2012).

Regarding the econometric approach, we follow the methodology generally used by the IMF for the external balance assessment (EBA), namely the feasible generalized least squares (FGLS) method, to deal with autocorrelation that is potentially present in the current account data (see e.g. Phillips et al., 2013). This method is known to account for heteroskedasticity as well as for temporal and spatial dependence in the residuals of time-series cross-sectional models and is therefore more efficient than standard methods that are robust to heteroskedasticity and/or autocorrelation (White and Newey-West) but that do not consider cross-sectional correlation (see Hoechle, 2007). More interestingly, this technique is more suitable when the temporal dimension of the panel data $(\mathrm{T})$ is greater than the individual dimension $(\mathrm{N})$, which is the case for our panel. As a robustness test, we also rely on a panelcorrected standard errors (PCSE) method that is complementary to the FGLS method. Indeed, the PCSE method is an alternative to the FGLS method for fitting linear cross-sectional timeseries models when the disturbances are not assumed to be independent and identically distributed (i.i.d.). Since the FGLS method tends to produce optimistic standard error estimates when the individual dimension is relatively large (greater than one-third of the temporal dimension), Beck and Katz (1995) recommend the use of PCSE in this case.

Table 4 reports the estimation results of equation (4). Several points can be made in reading the results. First, the two methods give very similar results, demonstrating the robustness of our results. Second, regarding our variable of interest, the results (FGLS1 and PCSE1) show that the misalignments have a negative overall impact on the current account. This expected result confirms that the current account is one of the main channels through which misalignments negatively affect economic growth, as is often documented in the literature

\footnotetext{
${ }^{17}$ Data sources for each series are presented in Table A.2 in Appendix.

${ }^{18}$ The prod squared is often introduced to account for possible non-linearity. But, this is inconclusive in our case and therefore it is not introduced.
} 
(Aguirre and Calderón, 2005; Schröder, 2013). From this point of view, these results usefully complement the previous studies on the link between economic growth and misalignments. They also show that misalignments are potentially one of the factors that explain the structural current account deficits in several countries of the CFA zone. Third, we find that there is a non-linear effect of misalignments insofar as the quadratic term of misalignments (mis squared, mis2) is significant (PCSE2). By focusing on the specific effects of misalignments - undervaluation and overvaluation - the results clearly confirm this nonlinear effect of misalignments. Indeed, the results indicate that real overvaluation leads to deterioration of the external balance while real undervaluation does not significantly promote an improvement in the current account. ${ }^{19}$ If the negative effects associated with exchange rate overvaluation are expected and consistent with the logic of international competitiveness, the insignificant impact of undervaluation is unexpected if the logic of international competitiveness is maintained.

However, these findings may have several explanations and implications. They show that the current state of the economies of the CFA zone would not allow them really to take advantage of periods of undervaluation. Indeed, to enjoy the undervaluation of the currency, the economies must be sufficiently dynamic and diversified to meet this type of shock by increasing their production and exports, otherwise they may suffer a "double penalty" to the extent that they will import more expensively. Beyond the weakness of productive structures, another potential explanation could come from the exchange rate policy, as shown above. Indeed, to the extent that undervaluation of the anchor currency leads to undervaluation of the CFA franc without this being an objective of the economic policy in the CFA zone, we cannot expect that such undervaluation would be beneficial to the economies of this area. Moreover, the negative effects of overvaluation would not necessarily, or only, be related to an international competitiveness problem but especially to the loss of export revenues and increased costs in imports to the extent that most of these countries are specialized in the exporting of US dollar-denominated commodities on the international market while they import more goods in euros. ${ }^{20}$

Finally, with regard to the control variables, these results are also consistent with the literature on the external balance assessment. Indeed, all the control variables have the signs established by the literature, thereby showing that our current account model was well estimated. For example, the "twin deficit" evidence (fiscal balance and external balance) is consistent with the predictions of overlapping generation models, as well as Blanchard's (1985) finite horizon model. In the same way, the initial net foreign assets and the oil balance are positively associated with the dynamics of the current account, as shown by most empirical studies (e.g. Chinn and Prasad, 2003; Lee et al., 2008; Ca' Zorzi et al., 2012; IMF, 2013). Moreover, the literature shows that the relative growth and demographic variables are negatively related to

\footnotetext{
${ }^{19}$ The graphs in Appendix $\mathrm{C}$ are in line with these results. The negative relationship between the episodes of overvaluation and the current account is sharper than the one that should be positive between the episodes of undervaluation and the current account. The current accounts remain structurally in deficit despite the undervaluation phases.

${ }^{20}$ According to UNCTAD data, 37\% of total imports of the CFA zone (41\% for CAEMC and $34 \%$ for WAEMU) comes from the euro area over the period 1995-2012.
} 
the current account (Chinn and Prasad, 2003; Christiansen et al, 2010; Phillips et al, 2013, among others). The negative relationship between financial deepening and the current account is also in line with several empirical studies (Gruber and Kamin, 2007; Cheung et al., 2013; Allegret et al., 2014), including those on the SSA countries (Gnimassoun, 2015). More trade openness is also often associated with a current account deficit (see Chinn and Prasad, 2003; Arezki and Hasanov, 2013; Allegret et al., 2014 among others).

Table 4: The effects of currency misalignments

\begin{tabular}{|c|c|c|c|c|c|c|}
\hline \multirow[b]{2}{*}{ VARIABLES } & \multicolumn{4}{|c|}{ Global effects } & \multicolumn{2}{|c|}{ Specific effects } \\
\hline & FGLS1 & PCSE1 & FGLS2 & PCSE2 & FGLS3 & PCSE3 \\
\hline mis & $\begin{array}{c}\mathbf{- 0 . 0 9 5 8} * * * \\
(0.0303)\end{array}$ & $\begin{array}{c}\mathbf{- 0 . 0 9 5 8 * * *} \\
(0.0219)\end{array}$ & $\begin{array}{c}\mathbf{- 0 . 0 8 8 0} * * * \\
(0.0284)\end{array}$ & $\begin{array}{c}\mathbf{- 0 . 0 8 8 0} * * * \\
(0.0206)\end{array}$ & & \\
\hline mis2 & & & $\begin{array}{c}-0.105 \\
(0.0658)\end{array}$ & $\begin{array}{c}\mathbf{- 0 . 1 0 5} * * \\
(0.0413)\end{array}$ & & \\
\hline under & & & & & $\begin{array}{c}-0.0536 \\
(0.0502)\end{array}$ & $\begin{array}{c}-0.0536 \\
(0.0338)\end{array}$ \\
\hline over & & & & & $\begin{array}{c}\mathbf{- 0 . 1 2 9} * * * \\
(0.0442)\end{array}$ & $\begin{array}{c}\mathbf{- 0 . 1 2 9} * * * \\
(0.0323)\end{array}$ \\
\hline$n f a$ & $\begin{array}{c}0.0349 * * * \\
(0.0134)\end{array}$ & $\begin{array}{c}0.0349 * * \\
(0.0156)\end{array}$ & $\begin{array}{c}0.0345 * * * \\
(0.0133)\end{array}$ & $\begin{array}{c}0.0345 * * \\
(0.0157)\end{array}$ & $\begin{array}{c}0.0340 * * \\
(0.0133)\end{array}$ & $\begin{array}{c}0.0340 * * \\
(0.0156)\end{array}$ \\
\hline fis & $\begin{array}{l}0.0904 * \\
(0.0547)\end{array}$ & $\begin{array}{c}0.0904 * * \\
(0.0421)\end{array}$ & $\begin{array}{l}0.0959 * \\
(0.0558)\end{array}$ & $\begin{array}{c}0.0959 * * \\
(0.0436)\end{array}$ & $\begin{array}{l}0.0959 * \\
(0.0553)\end{array}$ & $\begin{array}{c}0.0959 * * \\
(0.0429)\end{array}$ \\
\hline rgrw & $\begin{array}{l}-0.105^{*} \\
(0.0558)\end{array}$ & $\begin{array}{c}-0.105^{* *} \\
(0.0443)\end{array}$ & $\begin{array}{l}-0.102 * \\
(0.0565)\end{array}$ & $\begin{array}{c}-0.102 * * \\
(0.0451)\end{array}$ & $\begin{array}{l}-0.107^{*} \\
(0.0560)\end{array}$ & $\begin{array}{l}-0.107 * * \\
(0.0448)\end{array}$ \\
\hline prod & $\begin{array}{c}-0.175 * * * \\
(0.0477)\end{array}$ & $\begin{array}{c}-0.175 * * * \\
(0.0467)\end{array}$ & $\begin{array}{c}-0.183 * * * \\
(0.0462)\end{array}$ & $\begin{array}{c}-0.183 * * * \\
(0.0455)\end{array}$ & $\begin{array}{c}-0.181 * * * \\
(0.0468)\end{array}$ & $\begin{array}{c}-0.181 * * * \\
(0.0463)\end{array}$ \\
\hline ry & $\begin{array}{c}-0.152 * * * \\
(0.0271)\end{array}$ & $\begin{array}{c}-0.152 * * * \\
(0.0237)\end{array}$ & $\begin{array}{c}-0.157 * * * \\
(0.0260)\end{array}$ & $\begin{array}{c}-0.157 * * * \\
(0.0227)\end{array}$ & $\begin{array}{c}-0.154 * * * \\
(0.0265)\end{array}$ & $\begin{array}{c}-0.154 * * * \\
(0.0235)\end{array}$ \\
\hline ro & $\begin{array}{c}-0.177 * * \\
(0.0884)\end{array}$ & $\begin{array}{c}-0.177 * * * \\
(0.0644)\end{array}$ & $\begin{array}{l}-0.196 * * \\
(0.0788)\end{array}$ & $\begin{array}{c}-0.196 * * * \\
(0.0595)\end{array}$ & $\begin{array}{l}-0.187 * * \\
(0.0829)\end{array}$ & $\begin{array}{c}-0.187 * * * \\
(0.0615)\end{array}$ \\
\hline rpopg & $\begin{array}{c}-3.014 * * \\
(1.353)\end{array}$ & $\begin{array}{c}-3.014 * * * \\
(1.034)\end{array}$ & $\begin{array}{c}-3.208 * * * \\
(1.218)\end{array}$ & $\begin{array}{c}-3.208 * * * \\
(0.928)\end{array}$ & $\begin{array}{c}-3.119 * * \\
(1.280)\end{array}$ & $\begin{array}{c}-3.119 * * * \\
(0.972)\end{array}$ \\
\hline oilb & $\begin{array}{c}0.682 * * * \\
(0.0463)\end{array}$ & $\begin{array}{c}0.682 * * * \\
(0.0550)\end{array}$ & $\begin{array}{c}0.685 * * * \\
(0.0458)\end{array}$ & $\begin{array}{c}0.685 * * * \\
(0.0544)\end{array}$ & $\begin{array}{c}0.684 * * * \\
(0.0463)\end{array}$ & $\begin{array}{c}0.684 * * * \\
(0.0546)\end{array}$ \\
\hline open & $\begin{array}{c}-0.119 * * * \\
(0.0341)\end{array}$ & $\begin{array}{c}-0.119 * * * \\
(0.0314)\end{array}$ & $\begin{array}{c}-0.127 * * * \\
(0.0332)\end{array}$ & $\begin{array}{c}-0.127 * * * \\
(0.0303)\end{array}$ & $\begin{array}{c}-0.122 * * * \\
(0.0336)\end{array}$ & $\begin{array}{c}-0.122 * * * \\
(0.0307)\end{array}$ \\
\hline fint & $\begin{array}{c}-0.0462 * * * \\
(0.0143)\end{array}$ & $\begin{array}{c}-0.0462 * * * \\
(0.0149)\end{array}$ & $\begin{array}{c}-0.0440 * * * \\
(0.0141)\end{array}$ & $\begin{array}{c}-0.0440 * * * \\
(0.0147)\end{array}$ & $\begin{array}{c}-0.0440 * * * \\
(0.0142)\end{array}$ & $\begin{array}{c}-0.0440 * * * \\
(0.0148)\end{array}$ \\
\hline tot & $\begin{array}{r}-0.00670 \\
(0.0121)\end{array}$ & $\begin{array}{l}-0.00670 \\
(0.00886)\end{array}$ & $\begin{array}{l}-0.0105 \\
(0.0110)\end{array}$ & $\begin{array}{c}-0.0105 \\
(0.00804)\end{array}$ & $\begin{array}{r}-0.00847 \\
(0.0115)\end{array}$ & $\begin{array}{l}-0.00847 \\
(0.00839)\end{array}$ \\
\hline dum94 & $\begin{array}{c}-0.00519 \\
(0.0157)\end{array}$ & $\begin{array}{c}-0.00519 \\
(0.0101)\end{array}$ & $\begin{array}{l}0.00652 \\
(0.0175)\end{array}$ & $\begin{array}{l}0.00652 \\
(0.0110)\end{array}$ & $\begin{array}{l}0.00285 \\
(0.0177)\end{array}$ & $\begin{array}{l}0.00285 \\
(0.0112)\end{array}$ \\
\hline Constant & $\begin{array}{c}0.598 * * * \\
(0.0986)\end{array}$ & $\begin{array}{c}0.598 * * * \\
(0.0914)\end{array}$ & $\begin{array}{c}0.636 * * * \\
(0.0964)\end{array}$ & $\begin{array}{c}0.636^{* * *} \\
(0.0911)\end{array}$ & $\begin{array}{c}0.619 * * * \\
(0.0983)\end{array}$ & $\begin{array}{c}0.619 * * * \\
(0.0936)\end{array}$ \\
\hline $\begin{array}{l}\text { Obs } \\
R \text {-saugred }\end{array}$ & 346 & $\begin{array}{c}346 \\
0518\end{array}$ & 346 & $\begin{array}{c}346 \\
0528\end{array}$ & 346 & $\begin{array}{l}346 \\
0524\end{array}$ \\
\hline $\begin{array}{l}R \text {-squared } \\
\text { N. of ident }\end{array}$ & 12 & $\begin{array}{c}0.518 \\
12 \\
\end{array}$ & 12 & $\begin{array}{c}0.528 \\
12 \\
\end{array}$ & 12 & $\begin{array}{c}0.524 \\
12 \\
\end{array}$ \\
\hline
\end{tabular}

Note: Robust standard errors are in parentheses; *** significant at the $1 \%$ level, ** significant at the 5\% level, * significant at the $10 \%$ level. 


\subsection{Structural current account deficits in the CFA zone: Does economic concentration matter?}

As discussed below, the structural current account deficits in the CFA zone are certainly not only due to misalignments and the anchor currency. Their effects are probably amplified by other economic structural factors in this zone, as in many SSA countries. Indeed, the strong specialization of these countries in the exporting of commodities does not leave enough room for a local dynamic productive structure, which limits the scope of any exchange rate policy, especially one aimed at improving international competitiveness. Although this policy does not really exist for the CFA zone due to the external anchor, one would hope that these economies are taking advantage of the favorable evolutions of the anchor currency, which is probably not the case in the light of our previous results.

To understand the role of structural features better, we investigate the influence of the strong specialization or lack of economic diversification on the current account - a fairly common feature of economies in SSA-while looking at the impact of misalignments. Specifically, we study the influence of export concentration on the current account and we check whether the impact of misalignments is linked to the latter. Accordingly, we use the index of export concentration built by UNCTAD. This index not only tells us that economies are vulnerable to external shocks because of their level of export concentration but also gives us an idea of the economic structure of the countries. Indeed, one might think that the most diversified economies have stronger domestic productive structures as well as strong institutions (see for example Gelb, 2011). Table A.1 in the appendix shows the index of export concentration by country and trade partner and Appendix B.2 presents the method of calculation of this index. This table clearly shows that the countries of the CFA zone have a high concentration of exports with a higher level of concentration for CAEMC countries, mainly oil producers.

However, data are available for this index only since 1995 and we cannot complete the period to the extent that the detailed data on exports required for this calculation also date back to 1995. Thus, we estimate an augmented version of equation (4) over the period 1995 to 2012 by adding the index of export concentration. Despite this new estimate having the disadvantage of being more limited in the number of observations due to the unavailability of data, it has the advantage of being a robustness analysis for the previous results. More specifically, this new estimate can allow us to check whether the negative impact of misalignments is still valid when considering the 1995-2012 period, which also corresponds to the post-CFA franc devaluation period. Table 5 presents the new results of the estimation of equation (4) with and without the inclusion of the index of export concentration.

Since the temporal dimension has been significantly reduced (even though $\mathrm{T}$ is always greater than N), the bias highlighted by Beck and Katz (1995) concerning the FGLS estimator may be more important. Thus, we prefer the results obtained from the PCSE method, but those obtained from the FGLS estimator and presented in Appendix A do not exhibit notable differences. The estimation results shown in Table 5 are presented in two parts. First, we replicate the previous estimates for the period 1995-2012 (the three first columns) as a robustness check. Then, the results of the augmented version of equation (4) are presented (the last four columns) to capture the influence of the concentration of exports. 
Several elements can be noted from reading these results. First, these results clearly reinforce the previous findings in that they show a negative overall impact of misalignments on the current account (Bench 1) with asymmetry in their impact (Bench 2). As before, overvaluation of the CFA franc negatively affects the external balance in the CFA zone, while undervaluation has no significant positive impact on the external balance (Bench 3). Second, by focusing on the influence of the concentration of exports, we find that it has a negative impact on the external balance of the CFA zone countries (Effect 1). More interestingly, the results show that the interaction between the misalignments and the concentration of exports has a significant negative impact on the current account (Effect 2). Given the asymmetric impact of misalignments (undervaluation and overvaluation), we then examine the specific effects taking into account the concentration of exports. The results still show that overvaluation degrades external performance in the CFA zone while undervaluation has no significant influence (Effect 3). Even more surprisingly, when we focus on the specific effects of misalignments crossed with the concentration of exports, we find that undervaluation has a significant negative impact on the current account (Effect 4). The interaction between export concentration and undervaluation is also significantly and negatively correlated with the current account. These results show that the concentration of exports and therefore the lack of economic diversification aggravate the negative effect of misalignments on the current account until an unexpected negative impact of undervaluation is involved. Table A.5 in Appendix showing the uncertainty in the current account and the concentration of exports by country, confirms the estimation results. This table clearly shows that countries with high uncertainty on the current account are those that have a low export diversification as Chad, Republic of Congo and Gabon. However, Senegal and Cameroon that have a low export concentration index also have a low uncertainty in the current account.

In summary, if exchange rate misalignments are detrimental to external performances in the CFA zone, they are still more harmful considering the lack of economic diversification. Indeed, export diversification would be a solution not only to cope with shocks of adverse terms of trade but also to dampen the adverse currency impacts related to the evolution of the anchor currency. This also offers the opportunity to take advantage of undervaluation phases induced by the anchor currency with a more dynamic economic structure.

Table 5: Export concentration effects

\begin{tabular}{|c|c|c|c|c|c|c|c|}
\hline \multirow[b]{3}{*}{ VARIABLES } & \multicolumn{7}{|c|}{ PCSE estimation } \\
\hline & \multicolumn{3}{|c|}{ Benchmark regression } & \multicolumn{4}{|c|}{ Augmented regression } \\
\hline & Bench1 & Bench2 & Bench3 & Effect 1 & Effect 2 & Effect 3 & Effect 4 \\
\hline mis & $\begin{array}{c}\mathbf{- 0 . 0 8 1 2 * * *} \\
(0.0329)\end{array}$ & $\begin{array}{c}\mathbf{- 0 . 0 7 7 4} * * * \\
(0.0301)\end{array}$ & & $\begin{array}{c}\mathbf{- 0 . 1 0 2} * * * \\
(0.0361)\end{array}$ & $\begin{array}{c}0.0427 \\
(0.0932)\end{array}$ & & \\
\hline mis2 & & $\begin{array}{l}\mathbf{- 0 . 1 7 3 *} \\
(0.0947)\end{array}$ & & & & & \\
\hline under & & & $\begin{array}{l}-0.0417 \\
(0.0596)\end{array}$ & & & $\begin{array}{l}-0.0819 \\
(0.0626)\end{array}$ & $\begin{array}{c}\mathbf{0 . 3 4 8} * * \\
(0.156)\end{array}$ \\
\hline over & & & $\begin{array}{l}-\mathbf{0 . 1 1 8} * * \\
(0.0513)\end{array}$ & & & $\begin{array}{c}-\mathbf{0 . 1 2 3}^{* *} * \\
(0.0558)\end{array}$ & $\begin{array}{l}-0.178 \\
(0.149)\end{array}$ \\
\hline conc & & & & $\begin{array}{c}\mathbf{- 0 . 0 8 6 1} * * * * \\
(0.0331)\end{array}$ & $\begin{array}{c}\mathbf{- 0 . 1 0 9} * * * \\
(0.0355)\end{array}$ & $\begin{array}{c}\mathbf{- 0 . 0 8 4 2} * * \\
(0.0333)\end{array}$ & $\begin{array}{c}-\mathbf{- 0 . 1 7 6}^{* * * *} \\
(0.0473)\end{array}$ \\
\hline
\end{tabular}




\begin{tabular}{|c|c|c|c|c|c|c|c|}
\hline misconc & & & & & $\begin{array}{c}\mathbf{- 0 . 2 9 3 *} \\
(0.177)\end{array}$ & & \\
\hline underconc & & & & & & & $\begin{array}{c}\mathbf{- 0 . 7 8 1} * * * \\
(0.275)\end{array}$ \\
\hline overconc & & & & & & & $\begin{array}{l}0.0990 \\
(0.350)\end{array}$ \\
\hline$n f a$ & $\begin{array}{c}0.0750 * * * \\
(0.0159)\end{array}$ & $\begin{array}{c}0.0758 * * * \\
(0.0160)\end{array}$ & $\begin{array}{c}0.0745^{* * *} \\
(0.0160)\end{array}$ & $\begin{array}{c}0.0746 * * * \\
(0.0158)\end{array}$ & $\begin{array}{c}0.0755 * * * \\
(0.0158)\end{array}$ & $\begin{array}{c}0.0744 * * * \\
(0.0158)\end{array}$ & $\begin{array}{c}0.0742 * * * \\
(0.0158)\end{array}$ \\
\hline fis & $\begin{array}{c}0.0586 \\
(0.0479)\end{array}$ & $\begin{array}{c}0.0573 \\
(0.0482)\end{array}$ & $\begin{array}{c}0.0576 \\
(0.0483)\end{array}$ & $\begin{array}{c}0.0504 \\
(0.0464)\end{array}$ & $\begin{array}{c}0.0619 \\
(0.0473)\end{array}$ & $\begin{array}{c}0.0501 \\
(0.0468)\end{array}$ & $\begin{array}{c}0.0583 \\
(0.0482)\end{array}$ \\
\hline rgrowth & $\begin{array}{l}-0.172 * * \\
(0.0709)\end{array}$ & $\begin{array}{l}-0.173 * * \\
(0.0726)\end{array}$ & $\begin{array}{l}-0.173 * * \\
(0.0718)\end{array}$ & $\begin{array}{l}-0.153 * * \\
(0.0698)\end{array}$ & $\begin{array}{l}-0.142 * * \\
(0.0688)\end{array}$ & $\begin{array}{l}-0.150 * * \\
(0.0701)\end{array}$ & $\begin{array}{l}-0.116^{*} \\
(0.0687)\end{array}$ \\
\hline rprod & $\begin{array}{c}-0.242 * * * \\
(0.0561)\end{array}$ & $\begin{array}{c}-0.252 * * * \\
(0.0573)\end{array}$ & $\begin{array}{c}-0.248 * * * \\
(0.0577)\end{array}$ & $\begin{array}{c}-0.228 * * * \\
(0.0579)\end{array}$ & $\begin{array}{c}-0.232 * * * \\
(0.0560)\end{array}$ & $\begin{array}{c}-0.234 * * * \\
(0.0601)\end{array}$ & $\begin{array}{c}-0.237 * * * \\
(0.0574)\end{array}$ \\
\hline$r y$ & $\begin{array}{c}-0.177 * * * \\
(0.0298)\end{array}$ & $\begin{array}{c}-0.181^{* * * *} \\
(0.0299)\end{array}$ & $\begin{array}{c}-0.180 * * * \\
(0.0300)\end{array}$ & $\begin{array}{c}-0.140 * * * \\
(0.0356)\end{array}$ & $\begin{array}{c}-0.133^{* * * *} \\
(0.0344)\end{array}$ & $\begin{array}{c}-0.144 * * * \\
(0.0359)\end{array}$ & $\begin{array}{c}-0.141 * * * \\
(0.0343)\end{array}$ \\
\hline ro & $\begin{array}{c}-0.226 * * * \\
(0.0758)\end{array}$ & $\begin{array}{c}-0.244 * * * \\
(0.0713)\end{array}$ & $\begin{array}{c}-0.234 * * * \\
(0.0714)\end{array}$ & $\begin{array}{c}-0.139 \\
(0.0864)\end{array}$ & $\begin{array}{c}-0.121 \\
(0.0831)\end{array}$ & $\begin{array}{l}-0.149 * \\
(0.0847)\end{array}$ & $\begin{array}{l}-0.141 * \\
(0.0788)\end{array}$ \\
\hline rpopg & $\begin{array}{c}-4.112 * * * \\
(1.434)\end{array}$ & $\begin{array}{c}-4.441 * * * \\
(1.258)\end{array}$ & $\begin{array}{c}-4.167 * * * \\
(1.303)\end{array}$ & $\begin{array}{c}-4.400 * * * \\
(1.558)\end{array}$ & $\begin{array}{c}-4.004 * * \\
(1.590)\end{array}$ & $\begin{array}{c}-4.527 * * * \\
(1.504)\end{array}$ & $\begin{array}{c}-4.257 * * * \\
(1.569)\end{array}$ \\
\hline oilb & $\begin{array}{c}0.696 * * * \\
(0.0479)\end{array}$ & $\begin{array}{c}0.695 * * * \\
(0.0493)\end{array}$ & $\begin{array}{c}0.695 * * * \\
(0.0489)\end{array}$ & $\begin{array}{c}0.719 * * * \\
(0.0509)\end{array}$ & $\begin{array}{c}0.739 * * * \\
(0.0510)\end{array}$ & $\begin{array}{c}0.719 * * * \\
(0.0511)\end{array}$ & $\begin{array}{c}0.747 * * * \\
(0.0500)\end{array}$ \\
\hline open & $\begin{array}{c}-0.118 * * * \\
(0.0427)\end{array}$ & $\begin{array}{c}-0.116^{* * * *} \\
(0.0405)\end{array}$ & $\begin{array}{c}-0.115^{* * * *} \\
(0.0411)\end{array}$ & $\begin{array}{c}-0.105^{* *} \\
(0.0439)\end{array}$ & $\begin{array}{c}-0.103 * * \\
(0.0434)\end{array}$ & $\begin{array}{c}-0.102 * * \\
(0.0431)\end{array}$ & $\begin{array}{c}-0.101 * * \\
(0.0418)\end{array}$ \\
\hline fint & $\begin{array}{c}-0.0683 * * * \\
(0.0182)\end{array}$ & $\begin{array}{c}-0.0679 * * * \\
(0.0181)\end{array}$ & $\begin{array}{c}-0.0672 * * * \\
(0.0181)\end{array}$ & $\begin{array}{c}-0.0675 * * * \\
(0.0178)\end{array}$ & $\begin{array}{c}-0.0632 * * * \\
(0.0182)\end{array}$ & $\begin{array}{c}-0.0668 * * * \\
(0.0178)\end{array}$ & $\begin{array}{c}-0.0650 * * * \\
(0.0179)\end{array}$ \\
\hline tot & $\begin{array}{c}-0.0134 \\
(0.0158)\end{array}$ & $\begin{array}{c}-0.0137 \\
(0.0159)\end{array}$ & $\begin{array}{l}-0.0123 \\
(0.0159)\end{array}$ & $\begin{array}{r}-0.00801 \\
(0.0160)\end{array}$ & $\begin{array}{c}-0.000254 \\
(0.0166)\end{array}$ & $\begin{array}{l}-0.00737 \\
(0.0161)\end{array}$ & $\begin{array}{l}0.00174 \\
(0.0164)\end{array}$ \\
\hline Constant & $\begin{array}{c}0.776 * * * \\
(0.105)\end{array}$ & $\begin{array}{c}0.807 * * * \\
(0.106)\end{array}$ & $\begin{array}{c}0.791 * * * \\
(0.106)\end{array}$ & $\begin{array}{c}0.677 * * * \\
(0.117)\end{array}$ & $\begin{array}{c}0.639 * * * \\
(0.114)\end{array}$ & $\begin{array}{c}0.692 * * * \\
(0.121)\end{array}$ & $\begin{array}{c}0.713 * * * \\
(0.117)\end{array}$ \\
\hline Obs. & 204 & 204 & 204 & 204 & 204 & 204 & 204 \\
\hline$R$-squared & 0.804 & 0.800 & 0.799 & 0.785 & 0.788 & 0.782 & 0.789 \\
\hline N. of ident & 12 & 12 & 12 & 12 & 12 & 12 & 12 \\
\hline
\end{tabular}

Note: Robust standard errors are in parentheses; $* * *$ significant at the $1 \%$ level, ** significant at the 5\% level, * significant at the $10 \%$ level.

\section{General discussions and policy implications}

Currency misalignments in the CFA zone, the origin of which is twofold (structural factors and anchor currency), have a negative asymmetrical impact on the current account. While overvaluation of the CFA franc deteriorates the current account, undervaluation does not improve it. The negative impact of misalignments is exacerbated by the concentration of exports. These results raise several comments in the light of the previous literature. Although the negative impact of overvaluation is expected and consistent with other studies showing a negative impact of misalignments on growth (Cottani et al., 1990; Ghura and Grennes, 1993; among others), the negligible or even negative impact of undervaluation contrasts with some recent empirical results. For example, Rodrik (2008) develops theoretical and empirical arguments that a deliberate policy of undervaluation could be beneficial for developing countries from the perspective of the revitalization of manufacturing exports. The findings of Nouira et al. (2011) support this thesis. These authors find that a number of developing 
countries have used a deliberate policy of undervaluation to boost the price competitiveness of manufactured exports. However, it should be emphasized that such a strategy is unlikely, if not impossible, for some countries, in particular those of the CFA zone. Indeed, because of the peg to the euro, a proactive exchange rate policy is no longer possible for the area and its members, which are rather "exchange rate policy takers" than "exchange rate policy makers." It is therefore not possible by definition to use a deliberate policy of undervaluation, at least a policy based on the nominal exchange rate, to stimulate the manufacturing sector. In such an exchange rate system, the evolution of the anchor currency plays an important role in the evolution of the competitiveness of countries with a pegged exchange rate, as we have previously shown. If overvaluation of the CFA franc has a negative impact on the external balance, undervaluation has not had a positive impact so far. This can be explained by the fact that the undervaluation is generally exogenous for these countries to the extent that it would not be an objective of economic policy but would result from "favorable evolution" of the anchor currency. In these circumstances, countries may not be willing to respond to this favorable shock by increasing their production and exports, which reduces their propensity to improve their current account. This makes it even more likely that economies will be poorly diversified. Indeed, our results show that the concentration of exports on a limited number of products (mainly commodities) alters the potential positive impact of undervaluation into a real negative impact on the current account. An obvious implication of economic policy consistent with these results is the establishment of an economic diversification policy. If export diversification helps to limit the impact of uncertainty on the terms of trade (Hesse, 2008), it seems essential for small highly specialized economies with a fixed exchange rate regime that reduces their leeway to conduct a proactive policy of undervaluation. Our results are to some extent consistent with the results of Schröder (2013), which show that developing countries should minimize their misalignments - undervaluation and overvaluation-that are indifferently harmful to growth. Although our study leads us to the same conclusion, it differs in that it specifically examines countries with a currency anchor system in which the control of misalignments seems difficult. Indeed, as we show above, misalignments (undervaluation and overvaluation) are mainly due to changes in the anchor currency and in the terms of trade, over which these countries have no control. Since such an exchange rate regime also has several benefits at the national level, especially in terms of price stability, prudence in the management of fiscal policy and the attractiveness of FDI, more economic diversification seems useful to deal with external uncertainties (terms of trade and anchor currency) and therefore minimize the exchange rate misalignments.

\section{Conclusion}

While currency misalignments have always been a major topic of interest due to the economic policy implications that they may raise at both the national and the international level, this issue has aroused more interest due to the growing external imbalances during the 2000s. While most studies agree that exchange rate distortions (misalignments) are generally harmful to growth, there is no consensus on their specific impact, especially for developing countries.

In this study, we explore one of the main channels of the transmission of misalignments to growth. Specifically, we study the impact of misalignments on the external balance, paying 
particular attention to the influence of the concentration of exports under a monetary union with an external anchor. To this end, we rely on the behavioral approach of the equilibrium exchange rate and address the key issue related to the choice of the fundamentals by relying on the Bayesian model averaging (BMA) and the general-to-specific (GETS) methods.

Our results show that the evolution of the real effective exchange rate in the CFA zone is mainly driven by government consumption, terms of trade and relative productivity (BalassaSamuelson effect). By focusing on the origin of misalignments, we clearly show that they depend mainly on changes in the anchor currency and deviations of the terms of trade from their structural level. We then analyze the impact of misalignments on the current account and we find that misalignments of the CFA franc adversely affect the current account but asymmetrically. Indeed, while the episodes of CFA franc overvaluation were significantly detrimental to the current account, the undervaluation episodes were not favorable for the current account. More interestingly, we find that the negative impact of misalignments is exacerbated by export concentration up to altering the negligible positive impact of undervaluation into a real negative and significant impact. These results support the structural reforms to diversify exports, an avenue which is crucial for these countries that are "price takers" concerning the terms of trade, as well as the nominal exchange rate.

\section{References}

Abdih, Y. and C. G. Tsangarides (2010) 'FEER for the CFA franc', Applied Economics 42, 2009-2029.

Aguirre, A. and C. Calderón (2005) 'Real Exchange Rate Misalignments and Economic Performance', Working Paper 315. Santiago: Central Bank of Chile, Economic Research Division.

Allegret, J.-P., C. Couharde, D. Coulibaly and V. Mignon (2013) 'Current accounts and oil price fluctuations in oil-exporting countries: the role of financial development' Journal of International Money and Finance 47, 185-201.

Arezki, R. and F. Hasanov (2013) 'Global Imbalances and Petrodollars', World Economy 36, 213-232.

Aydin, B. (2010) 'Exchange Rate Assessment for Sub-Saharan Economies', IMF Working Paper 10/162.

Baffes, J., I. A. Elbadawi and S. A. O'Connell (1999) 'Single-equation estimation of the equilibrium exchange rate' L.E. Hinkle, P.J. Montiel (Eds.), Exchange Rate Misalignment: Concepts and Measurement for Developing Countries, A World Bank Research Publication, Oxford University Press, pp. 405-464.

Bahmani-Oskooee M. and A. Gelan (2006) 'Testing the PPP in the Non-Linear STAR Framework: Evidence from Africa', Economics Bulletin 6, 1-15.

Barro, R. J. (1991) 'Economic Growth in a Cross Section of Countries', Quarterly Journal of Economics 106(2), 407-443. 
Beck, N. and Jonathan N. Katz (1995) 'What to do (and not to do) with time-series crosssection data'. American Political Science Review 89, 634-647.

Belke, A. and C. Dreger (2013) Current Account Imbalances in the Euro Area: Does Catching up Explain the Development?, Review of International Economics 21, 6-17.

Béreau, S., A. L. Villavicencio and V. Mignon (2012) 'Currency misalignments and growth: a new look using nonlinear panel data methods', Applied Economics 44, 3503-3511.

Berg, A. and Y. Miao (2010) 'The real exchange rate and growth revisited: The Washington Consensus strikes back?', IMF Working Papers, 1-24.

Bergsten, F. C. (2010). 'Correcting the Chinese Exchange Rate. Testimony before the Hearing on China's Exchange Rate Policy', Committee on Ways and Means, US House of Representatives.

Blanchard, O. J. (1985) 'Debt, deficits and finite horizons', Journal Political Economy 93(2), 223-247.

Bleaney, M. and D. Greenaway (2001) 'The impact of terms of trade and real exchange rate volatility on investment and growth in sub-Saharan Africa' Journal of development Economics 65, 491-500.

Ca' Zorzi, M. A. Chudik and A. Dieppe (2012) 'Thousands of models, one story: current account imbalances in the global economy' Journal of International Money and Finance 31, 1319-1338.

Candelon, B., C. Kool, K. Raabe and T. Veen (2007) 'Long-run real exchange rate determinants: evidence from eight new EU member states 1993-2003', Journal of Comparative Economics 35, 87-107.

Carrion-I-Silvestre, J. L., T. D. Barrio-Castro and E. Lopez-Bazo (2005) 'Breaking the panels: An application to GDP per capita' Econometrics Journal 8, 159-175.

Cheung, C., D. Furceri and E. Rusticelli (2013) 'Structural and Cyclical Factors behind Current Account Balances', Review of International Economics 21, 923-944.

Chinn, M. D., and E. S. Prasad (2003) 'Medium-term determinants of current accounts in industrial and developing countries: an empirical exploration', Journal of International Economics, 59(1), 47-76.

Chinn, M. D. and H. Ito (2006) 'What Matters for Financial Development? Capital Controls, Institutions, and Interactions', Journal of Development Economics 81, 163-192.

Christiansen, L. E., A. Prati, L. A. Ricci and T. Tressel (2010) 'External balance in lowincome countries', In: NBER International Seminar on Macroeconomics 2009. University of Chicago Press, pp. 265-322.

Clark, P. B. and R. MacDonald (1998) 'Exchange Rates and Economic Fundamentals: A Methodological Comparison of BEERs and FEERs', IMF Working Papers 98/67.

Clarke, D. (2014) 'General to specific modelling in Stata', Stata Journal 14 (4), 895-908. 
Cottani, J. A., D. F. Cavallo and S. M. Khan (1990) 'Real exchange rate behavior and economic performance in LDCs', Economic Development and Cultural Change 39, 61-76.

Coudert, V., C. Couharde (2009) 'Currency Misalignments and Exchange Rate Regimes in Emerging and Developing Countries', Review of International Economics 17, 121-136.

Couharde, C. and A. Sallenave (2013) 'How do currency misalignments' threshold affect economic growth?', Journal of Macroeconomics 36, 106-120.

Couharde, C., I Coulibaly and D. Damette (2013) 'Anchor currency and real exchange rate dynamics in the CFA Franc zone', Economic Modelling 33, 722-732.

Couharde, C., I. Coulibaly, D. Guerreiro and V. Mignon (2013) 'Revisiting the theory of optimum currency areas: Is the CFA franc zone sustainable?', Journal of Macroeconomics, $38,428-441$.

Coulibaly, I. and B. Gnimassoun (2013) 'Optimality of a monetary union : New evidence from exchange rate misalignments in West Africa', Economic Modelling 32, 463-482.

Devarajan, S. (1997) 'Real exchange rate misalignment in the CFA zone', Journal of African Economies 6, 35-53.

Ding, S. and J. Knight (2011) 'Why has China grown so fast? the role of physical and human capital formation', Oxford Bulletin of Economics and Statistics, 73(2), 141-174.

Driver, R L. and P. F. Westaway (2005) 'Concepts of equilibrium exchange rates', In: Driver, R., Sinclair, P., Thoenissen, C. (Eds.), Exchange Rates, Capital Flows and Policy. Routledge.

Dubas, J. M. (2009) 'The importance of the exchange rate regime in limiting misalignment', World Development 37, 1612-1622.

Edwards, S. (1988) 'Real and monetary determinants of real exchange rate behavior: Theory and evidence from developing countries' Journal of Development Economics 29, 311-341.

Edwards, S. (1989) 'Exchange Rate Misalignment in Developing Countries', World Bank Research Observer, World Bank Group 4, 3-21.

Elbadawi, I. A., (1994) 'Estimating long-run equilibrium exchange rates' J. Williamson (Ed.), Estimating Equilibrium Exchange Rates, Institute for International Economics, Washington D.C. pp. 93-132.

Elbadawi, I. A., L. Kaltani and R. Soto (2012) 'Aid, real exchange rate misalignment, and economic growth in Sub-Saharan Africa', World Development 40(4), 681-700.

Faruqee, Hamid, 1995. Long-Run Determinants of the Real Exchange Rate: A Stock-Flow Perspective. IMF Staff Papers 42, 80-107.

Fernandez, C., E. Ley, Steel and F. J. Mark (2001) 'Model uncertainty in cross-country growth regressions', Journal of Applied Econometrics 16, 563-576.

Gala, P. (2008) 'Real exchange rate levels and economic development: theoretical analysis and econometric evidence', Cambridge Journal of economics 32, 273-288. 
Gelb, A. (2011) 'Economic Diversification in Resource Rich Countries'. Center for Global Development mimeo.

Ghosh A. R. and J. D. Ostry (1994) 'Export instability and the external balance in developing countries’ IMF Staff Papers 41, 214-235.

Ghura, D. and T. J. Grennes (1993) 'The real exchange rate and macroeconomic performance in Sub-Saharan Africa', Journal of Development Economics 42, 155-174.

Gnimassoun, B. (2015) 'The importance of the exchange rate regime in limiting current account imbalances in sub-Saharan African countries', Journal of International Money and Finance 53, 36-74.

Gnimassoun, B. and I. Coulibaly (2014) 'Current account sustainability in Sub-Saharan Africa: Does the exchange rate regime matter?', Economic Modelling 40, 208-226.

Gnimassoun, B. and V. Mignon (2014) 'Persistence of current-account disequilibria and real exchange-rate misalignments’, Review of International Economics 23, 137-159.

Goldstein, M. (2010) 'Confronting Asset Bubbles, Too Big to Fail, and Beggar-thy-Neighbor Exchange Rate Policies', Policy Brief 10-3, Peterson Institute for International Economics.

Gruber, J. W. and S. B. Kamin, (2007) 'Explaining the global pattern of current account imbalances. Journal of International Money and Finance 26, 500-522.

Hendry, D. F. and H.-M. Krolzig (2004) 'We Ran One Regression', Oxford Bulletin of Economics and Statistics 66, 799-810.

Hesse, H. (2008) 'Export Diversification and Economic Growth', Working Paper 21, World Bank: Commission on Growth and Development Washington, DC.

Hoechle, D. (2007) 'Robust standard errors for panel regressions with cross-sectional dependence', Stata Journal 7(3), 281-312.

Hoover, K. D. and S. J. Perez (2004) 'Truth and robustness in cross-country growth regressions', Oxford Bulletin of Economics and Statistics 66, 765-798.

International Monetary Fund, (2013) 'External Balance Assessment (EBA) Methodology: Technical Background', IMF Research Department, International Monetary Fund, Washington/DC.

Lane, P. R. and G. M. Milesi-Ferretti (2012) 'External adjustment and the global crisis', Journal of International Economics, 882, 252-265.

Lee, J., G. M. Milesi-Ferretti, J. D. Ostry, A. Prati, L. Ricci (2008) Exchange Rate Assessments: CGER Methodologies. IMF Occasional Paper 261.

MacDonald, R. (1997) 'What Determines Real Exchange Rates?', The Long and Short of It. IMF Working paper 97/21.

Mark, N. C. and D. Sul (2003) 'Cointegration Vector Estimation by Panel DOLS and Long run Money Demand', Oxford Bulletin of Economics and Statistics 65, 655-680. 
Mongardini, Joannes, Rayner, Brett, (2009) Grants, Remittances, and the Equilibrium Real Exchange Rate in Sub-Saharan African Countries. IMF Working Paper, 09/75.

Moral-Benito, E. (2012) 'Determinants of economic growth: a Bayesian panel data approach', Review of Economics and Statistics 94, 566-579.

Nouira, R., P. Plane and K. Sekkat (2011) 'Exchange rate undervaluation and manufactured exports: A deliberate strategy?', Journal of Comparative Economics, 39, 584-601.

Obstfeld, M. and K. S. Rogoff (2005) 'Global current account imbalances and exchange rate adjustments', Brookings papers on economic activity 1, 67-146.

Odedokun, M. O. (2000) 'Fulfilment of Purchasing Power Parity Conditions in Africa: The Differential Role of CFA and Non-CFA Membership', Journal of African Economies 9, 213234.

Ouattara, B. and E. Strobl (2008) 'Foreign aid inflows and the real exchange rate in the CFA Franc zone', International Economics 116, 37-52.

Owen, Dorian P., (2003) 'General-to-Specific modelling using Pcgets', Journal of Economic Surveys 17, 609-627.

Pesaran, M. H., Y. Shin and R. P. Smith (1999) 'Pooled Mean Group Estimation of Dynamic Heterogeneous Panel', Journal of the American Statistical Association 94, 621-634.

Phillips S., L. Catão, L. Ricci, R. Bems, M. Das, J. Di Giovanni, D.F. Unsal, M. Castillo, J. Lee, J. Rodriguez, M. Vargas (2013) The External Balance Assessment (EBA) Methodology. IMF Working Paper No 13/272.

Razin, O. and S. M. Collins (1997) 'Real Exchange Rate Misalignments and Growth', NBER Working Paper 6174.

Rodrik, D. (2008) 'The real exchange rate and economic growth', Brookings papers on economic activity 2, 365-412.

Roudet, S., M. Saxegaard and C. G. Tsangarides (2007) 'Estimation of equilibrium exchange rates in the WAEMU: a robustness approach', IMF Working Paper 07/194.

Sala-i-Martin, X. (1997) 'I just ran two million regressions', American Economic Review 87, 178-183.

Schröder, M. (2013) 'Should countries undervalue their currencies?', Journal of Development Economics 105, 140-151.

Stockman, A. C. (1999) 'Choosing an exchange-rate system', Journal of Banking and Finance 23, 1483-1498.

Westerlund, J. (2007) 'Testing for Error Correction in Panel Data', Oxford Bulletin of Economics and Statistics 69, 709-748.

Williamson, J. (1985) 'The Exchange Rate System', 2nd ed., Washington, DC: Institute for International Economics. 
Williamson, J. (1990) 'What Washington means by policy reform', J. Williamson (Ed.), Latin American Adjustment: How Much Has Happened?, Peterson Institute for International Economics, 5-20.

Zhang, Z. (2001) 'Real Exchange Rate Misalignment in China: An Empirical Investigation', Journal of Comparative Economics 29, 80-94. 


\section{Appendix}

Table A.1: Countries and their main trade partners

\section{Appendix A: Tables}

\begin{tabular}{|c|c|c|c|c|c|c|c|c|c|c|c|c|c|c|c|c|c|c|c|c|c|c|}
\hline \multirow{3}{*}{$\begin{array}{l}\text { Country } \\
\text { Benin }\end{array}$} & \multicolumn{20}{|c|}{ Main trade partners } & \multirow[t]{2}{*}{ Sum } & \multirow[t]{2}{*}{ W. Mean } \\
\hline & \multicolumn{2}{|c|}{ China } & \multicolumn{2}{|c|}{ France } & \multicolumn{2}{|c|}{ India } & \multicolumn{2}{|c|}{ Nigeria } & \multicolumn{2}{|c|}{ Thailand } & \multicolumn{2}{|c|}{ USA } & \multicolumn{2}{|c|}{ Netherlands } & \multicolumn{2}{|c|}{ Malaysia } & \multicolumn{2}{|c|}{ Brazil } & \multicolumn{2}{|c|}{ Mali } & & \\
\hline & $23.1 \%$ & 0.79 & $8.2 \%$ & $\underline{0.40}$ & $7.4 \%$ & 0.57 & $4.6 \%$ & 0.53 & $4.4 \%$ & 0.85 & $4.2 \%$ & 0.53 & $2.8 \%$ & 0.60 & $2.6 \%$ & 0.79 & $2.5 \%$ & 0.96 & $2.5 \%$ & 0.91 & $62.5 \%$ & $\underline{0.68}$ \\
\hline Burkina & \multicolumn{2}{|c|}{ France } & \multicolumn{2}{|c|}{ Ivory Coast } & \multicolumn{2}{|c|}{ Switzerland } & \multicolumn{2}{|c|}{ China } & \multicolumn{2}{|c|}{ Togo } & \multicolumn{2}{|c|}{ Ghana } & \multicolumn{2}{|c|}{ Belgium } & \multicolumn{2}{|c|}{ India } & \multicolumn{4}{|c|}{ USA } & & \\
\hline Cameroon & Frar & & Ita & & $\mathrm{Sp}$ & & $\mathrm{Ch}$ & & $\mathrm{Nig}$ & ria & Nethe & lands & Us & $\mathrm{A}$ & Belg & um & Gern & lany & $\mathrm{U}$ & & & \\
\hline & $16.3 \%$ & $\underline{0.36}$ & $8.8 \%$ & $\underline{0.58}$ & $8.5 \%$ & $\underline{0.73}$ & $8.1 \%$ & $\underline{0.57}$ & $7.5 \%$ & $\underline{0.42}$ & $5.6 \%$ & $\underline{0.69}$ & $5.3 \%$ & $\underline{0.53}$ & $4.3 \%$ & $\underline{0.46}$ & $3.3 \%$ & $\underline{0.36}$ & $2.5 \%$ & $\underline{0.47}$ & $70.1 \%$ & $\underline{0.51}$ \\
\hline CAF & Belg & um & Fran & & Came & oon & $\mathrm{Ko}$ & & Nethe & lands & $\mathrm{U}$ & & $\mathrm{Ch}$ & ina & $\mathrm{Sp}$ & & Jap & & Gerr & lany & & \\
\hline Chad & US & & Fran & & $\mathrm{Ch}$ & & Cam & oon & Port & igal & Ger & any & Nethe & rlands & $\mathrm{U}$ & & Belg & ium & Nig & & & \\
\hline & $51.4 \%$ & $\underline{0.85}$ & $12.1 \%$ & $\underline{0.80}$ & $6.2 \%$ & $\underline{0.80}$ & $4.5 \%$ & 0.42 & $4.0 \%$ & 0.73 & $3.2 \%$ & 0.81 & $1.8 \%$ & 0.61 & $1.7 \%$ & $\underline{0.77}$ & $1.7 \%$ & $\underline{0.85}$ & $1.2 \%$ & 0.39 & $88.0 \%$ & $\underline{0.80}$ \\
\hline Congo, & Chi & & US & & Fra & & $\mathrm{Ko}$ & & $\mathrm{It}$ & & $\mathrm{T}$ & & In & lia & Nethe & lands & $\mathrm{Sp}$ & & Gerr & lany & & \\
\hline Rep. & $24.2 \%$ & $\underline{0.83}$ & $22.1 \%$ & $\underline{0.81}$ & $10.3 \%$ & $\underline{0.62}$ & $4.7 \%$ & $\underline{0.94}$ & $3.7 \%$ & 0.56 & $3.5 \%$ & 0.94 & $3.3 \%$ & 0.52 & $2.8 \%$ & $\underline{0.70}$ & $2.1 \%$ & $\underline{0.50}$ & $1.9 \%$ & 0.64 & $78.6 \%$ & $\underline{0.77}$ \\
\hline Ivory & Frar & & Nige & & Nethe & $\overline{\text { ands }}$ & $\mathrm{US}$ & & Gerr & lany & & & $\mathrm{Sp}$ & ain & $\mathrm{Ch}$ & & $\mathrm{Gh}$ & & $\mathrm{U}$ & & & \\
\hline Coast & $16.5 \%$ & $\underline{0.35}$ & $12.9 \%$ & $\underline{0.72}$ & $8.3 \%$ & $\underline{0.85}$ & $6.7 \%$ & $\underline{0.69}$ & $4.2 \%$ & $\underline{0.68}$ & $3.4 \%$ & 0.36 & $2.7 \%$ & $\underline{0.38}$ & $2.6 \%$ & $\underline{0.59}$ & $2.3 \%$ & $\underline{0.33}$ & $2.3 \%$ & $\underline{0.52}$ & $62.0 \%$ & 0.57 \\
\hline Gabon & US & & Fran & & $\mathrm{Ch}$ & & $\mathrm{Sp}$ & & $\mathrm{T}$ & & $\mathrm{Ja}$ & & It: & ly & Nethe & $\overline{\text { lands }}$ & Gern & $\overline{\text { lany }}$ & Mal & ysia & & \\
\hline Mali & South & ffrica & Fran & & Sen & & Ivory & Coast & $\mathrm{Ch}$ & & Switz & rland & Gerr & nany & Belg & $\mathrm{um}$ & US & & Tha & and & & \\
\hline & $14.0 \%$ & $\underline{0.53}$ & $11.5 \%$ & $\underline{0.87}$ & $10.8 \%$ & $\underline{0.62}$ & $10.6 \%$ & $\underline{0.36}$ & $8.4 \%$ & $\underline{0.67}$ & $3.6 \%$ & $\underline{0.66}$ & $3.2 \%$ & 0.96 & $2.5 \%$ & $\underline{0.93}$ & $2.4 \%$ & $\underline{0.97}$ & $2.3 \%$ & $\underline{0.31}$ & $69.4 \%$ & $\underline{0.64}$ \\
\hline Niger & Frar & & Nige & & $\mathrm{Ch}$ & & $\mathrm{U}$ & & Ivory & Coast & & & Belg & ium & Nethe & lands & Inc & & $\mathrm{Ko}$ & & & \\
\hline & $22.4 \%$ & $\underline{0.57}$ & $12.3 \%$ & $\underline{0.40}$ & $9.1 \%$ & $\underline{0.59}$ & $8.0 \%$ & $\underline{0.72}$ & $4.1 \%$ & $\underline{0.42}$ & $2.8 \%$ & $\underline{0.73}$ & $2.7 \%$ & $\underline{0.73}$ & $2.6 \%$ & $\underline{0.63}$ & $2.6 \%$ & $\underline{0.58}$ & $2.3 \%$ & $\underline{0.55}$ & $68.8 \%$ & $\underline{0.57}$ \\
\hline Senegal & Frar & & Nige & ria & Inc & & $\mathrm{M}$ & & $\mathrm{U}$ & & $\mathrm{Ch}$ & & Ita & ly & $\mathrm{Sp}$ & & Nethe & $\overline{\text { lands }}$ & Tha & $\overline{\text { and }}$ & & \\
\hline & $18.8 \%$ & $\underline{0.31}$ & $6.5 \%$ & $\underline{0.42}$ & $6.2 \%$ & $\underline{0.76}$ & $5.5 \%$ & $\underline{0.44}$ & $5.0 \%$ & $\underline{0.32}$ & $4.4 \%$ & $\underline{0.46}$ & $4.2 \%$ & $\underline{0.46}$ & $3.8 \%$ & $\underline{0.59}$ & $3.4 \%$ & $\underline{0.34}$ & $3.1 \%$ & $\underline{0.58}$ & $60.8 \%$ & $\underline{0.44}$ \\
\hline Togo & Chi & & Fran & & $\mathrm{Gh}$ & & In & & Nethe & lands & Burkiı & Faso & $\mathrm{Nig}$ & eria & & & Ivory & Coast & Gerr & & & \\
\hline & $15.5 \%$ & $\underline{0.68}$ & $8.0 \%$ & $\underline{0.31}$ & $5.9 \%$ & $\underline{0.44}$ & $5.0 \%$ & $\underline{0.60}$ & $4.4 \%$ & $\underline{0.54}$ & $4.2 \%$ & $\underline{0.48}$ & $3.7 \%$ & 0.46 & $3.6 \%$ & $\underline{0.28}$ & $3.3 \%$ & $\underline{0.28}$ & $3.2 \%$ & 0.59 & $56.9 \%$ & $\underline{0.50}$ \\
\hline
\end{tabular}

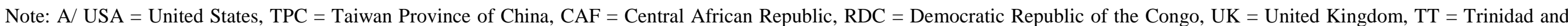
Tobago. Trade weights are in percent. Given that the sum of trade flows with the first ten trading partners is less than $100 \%$, the different weights were then normalized to $100 \%$.

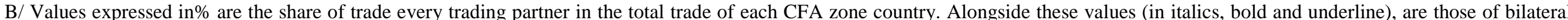

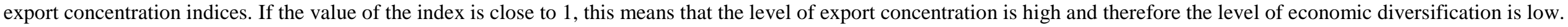


Table A.2: Data sources and Definition of the variables

\begin{tabular}{|c|c|c|c|}
\hline Primary data & Sources & Notation & Comments \\
\hline Real effective exchange rate & UNCTAD Statistics and author's calculation & reer & $\begin{array}{l}\text { Real effective exchange rates are the weighted averages of bilateral exchange } \\
\text { rates adjusted by relative consumer prices. }\end{array}$ \\
\hline Investment & WEO Database (IMF) & invest & $\%$ of GDP \\
\hline Government consumption & UNCTAD Statistics & gov & $\%$ of GDP \\
\hline Level of PPP-adjusted GDP per capita & WEO Database & prod & Relative to a weighted-average of country i's trading partners \\
\hline Capital control & Chinn and Ito (2006) database & kacont & Chinn-Ito index (1- kaopen) \\
\hline Money supply & WDI & $m 2$ & $\%$ of GDP \\
\hline Current account balance & WEO Database (IMF) & $c a$ & $\%$ of GDP \\
\hline $\begin{array}{l}\text { Net foreign asset to GDP ratio (Lagged } \\
\text { in CA regression) }\end{array}$ & $\begin{array}{l}\text { Updated and extended version of dataset } \\
\text { constructed by Lane and Milesi-Ferretti (2011) }\end{array}$ & $n f a$ & $\%$ of GDP \\
\hline Old-age dependency ratio & WDI (The World Bank) & ro & $\begin{array}{l}\text { Defined as the ratio of the population aged } 65 \text { and older to the working-age } \\
\text { population, and measured relative to a weighted average of country i's trading }\end{array}$ \\
\hline Young dependency ratio & WDI & ry & $\begin{array}{l}\text { Defined as the ratio of the population younger than } 15 \text { to the working-age } \\
\text { population, and measured relative to a weighted average of country i's trading }\end{array}$ \\
\hline Population growth rate & WDI & rpopg & Annual growth of total population \\
\hline Trade openness & WDI & topen & (Exports + Imports)/GDP. \\
\hline Oil balance & WEO & oilb & Oil trade balance in $\%$ of GDP \\
\hline Terms of trade & WDI & tot & Index, price of exports/price of imports \\
\hline Nominal effective exchange rate & UNCTAD Statistics and author's calculation & neer & Weighted averages of bilateral exchange rates. \\
\hline Financial integration & $\begin{array}{l}\text { Updated and extended version of dataset } \\
\text { constructed by Lane and Milesi-Ferretti (2011) }\end{array}$ & fint & Sum of external assets and liabilities in \% of GDP. \\
\hline Official Development Assistance & UNCTAD Statistics & oda & Net official development assistance (ODA), received, in \% of GDP. \\
\hline Trade openness & UNCTAD Statistics & open & \\
\hline World real interest rate & IFS (IMF) & wrir & $\begin{array}{l}\text { World nominal interest rate adjusted by CPI percentage change for OECD } \\
\text { countries. }\end{array}$ \\
\hline Civil liberties & FWS & $c l i b$ & Indexed between 1 (free) and 7 (no free). \\
\hline Foreign direct investment & UNCTAD Statistics & $f d i$ & Foreign direct investment, net inflows, in \% of GDP \\
\hline Migrants' Remittances & WDI & rem & Worker's remittances, receipts (\% of GDP) \\
\hline Export concentration index & UNCTAD Statistics & conc & Range between 0 (high diversification) and 1 (high concentration) \\
\hline
\end{tabular}


Table A.3: Relationship between CFA franc and the anchor currency (French franc)

\begin{tabular}{|c|c|c|c|c|c|c|}
\hline \multirow[b]{2}{*}{ VARIABLES } & \multicolumn{3}{|c|}{ NEER (CFA) } & \multicolumn{3}{|c|}{ REER (CFA) } \\
\hline & OLS & FE & GLS & OLS & $\mathrm{FE}$ & GLS \\
\hline NEER (France) & $\begin{array}{c}1.043 * * * \\
(0.0212)\end{array}$ & $\begin{array}{c}1.043 * * * \\
(0.0396)\end{array}$ & $\begin{array}{c}1.019 * * * \\
(0.0163)\end{array}$ & $\begin{array}{c}0.918 * * * \\
(0.0698)\end{array}$ & $\begin{array}{c}0.918 * * * \\
(0.0752)\end{array}$ & $\begin{array}{c}0.923 * * * \\
(0.0599)\end{array}$ \\
\hline dum94 & $\begin{array}{c}-0.675^{* * *} \\
(0.00970)\end{array}$ & $\begin{array}{c}-0.675^{* * *} \\
(0.00918)\end{array}$ & $\begin{array}{c}-0.684 * * * \\
(0.00368)\end{array}$ & $\begin{array}{c}-0.434 * * * \\
(0.0195)\end{array}$ & $\begin{array}{c}-0.434 * * * \\
(0.0212)\end{array}$ & $\begin{array}{c}-0.439 * * * \\
(0.0135)\end{array}$ \\
\hline Constant & $\begin{array}{c}0.00468 * * * \\
(0.000666)\end{array}$ & $\begin{array}{c}0.00468 * * * \\
(0.000423)\end{array}$ & $\begin{array}{c}0.00434 * * * \\
(0.000661)\end{array}$ & $\begin{array}{c}-0.0117 * * * \\
(0.00259)\end{array}$ & $\begin{array}{l}-0.0117 * * * \\
(0.000985)\end{array}$ & $\begin{array}{c}-0.0111 * * * \\
(0.00243)\end{array}$ \\
\hline $\begin{array}{l}\text { Observations } \\
\text { R-squared }\end{array}$ & $\begin{array}{c}384 \\
0.986\end{array}$ & $\begin{array}{c}384 \\
0.988\end{array}$ & 384 & $\begin{array}{c}384 \\
0.721\end{array}$ & $\begin{array}{c}384 \\
0.722\end{array}$ & 384 \\
\hline Number of id & & 12 & 12 & & 12 & 12 \\
\hline
\end{tabular}

Note: Robust standard errors are in parentheses, $* * * \mathrm{p}<0.01, * * \mathrm{p}<0.05, * \mathrm{p}<0.1$. The anchor currency is the nominal effective exchange rate of France given that the CFA franc was pegged to the French franc until 1998. The estimations cover the 1980-2012 period. The similarity in the results (OLS and fixed effects) is quite normal to the extent that the fluctuations of the anchor currency affect countries in the same way. The data are logarithmic variations. Dum94 is set to 1 in 1994 and zero elsewhere.

Table A.4: Export concentration effects

\begin{tabular}{|c|c|c|c|c|c|c|c|}
\hline \multirow[b]{3}{*}{ VARIABLES } & \multicolumn{7}{|c|}{ FGLS regression } \\
\hline & \multicolumn{3}{|c|}{ Benchmark regression } & \multicolumn{4}{|c|}{ Effects of export concentration } \\
\hline & Bench1 & Bench2 & Bench3 & Effect 1 & Effect 2 & Effect 3 & Effect 4 \\
\hline mis & $\begin{array}{c}-0.0812 * * \\
(0.0359)\end{array}$ & $\begin{array}{c}-0.0774 * * \\
(0.0328)\end{array}$ & & $\begin{array}{l}-0.102 * * \\
(0.0401)\end{array}$ & $\begin{array}{c}0.0427 \\
(0.0924)\end{array}$ & & \\
\hline $\operatorname{mis} 2$ & & $\begin{array}{l}-0.173 \\
(0.107)\end{array}$ & & & & & \\
\hline under & & & $\begin{array}{l}-0.0417 \\
(0.0575)\end{array}$ & & & $\begin{array}{l}-0.0819 \\
(0.0636)\end{array}$ & $\begin{array}{l}0.348 * \\
(0.179)\end{array}$ \\
\hline over & & & $\begin{array}{l}-0.118 * * \\
(0.0578)\end{array}$ & & & $\begin{array}{l}-0.123 * * \\
(0.0616)\end{array}$ & $\begin{array}{l}-0.178 \\
(0.142)\end{array}$ \\
\hline conc & & & & $\begin{array}{c}-0.0861 * * \\
(0.0373)\end{array}$ & $\begin{array}{c}-0.109 * * * \\
(0.0394)\end{array}$ & $\begin{array}{c}-0.0842 * * \\
(0.0378)\end{array}$ & $\begin{array}{c}-0.176 * * * \\
(0.0541)\end{array}$ \\
\hline misconc & & & & & $\begin{array}{l}-0.293 * \\
(0.169)\end{array}$ & & \\
\hline underconc & & & & & & & $\begin{array}{c}-0.781 * * \\
(0.306)\end{array}$ \\
\hline overconc & & & & & & & $\begin{array}{l}0.0990 \\
(0.287)\end{array}$ \\
\hline$n f a$ & $\begin{array}{c}0.0750 * * * \\
(0.0124)\end{array}$ & $\begin{array}{c}0.0758^{* * * *} \\
(0.0124)\end{array}$ & $\begin{array}{c}0.0745 * * * \\
(0.0124)\end{array}$ & $\begin{array}{c}0.0746 * * * \\
(0.0125)\end{array}$ & $\begin{array}{c}0.0755 * * * \\
(0.0124)\end{array}$ & $\begin{array}{c}0.0744 * * * \\
(0.0125)\end{array}$ & $\begin{array}{c}0.0742 * * * \\
(0.0123)\end{array}$ \\
\hline fis & $\begin{array}{c}0.0586 \\
(0.0487)\end{array}$ & $\begin{array}{c}0.0573 \\
(0.0489)\end{array}$ & $\begin{array}{c}0.0576 \\
(0.0489)\end{array}$ & $\begin{array}{c}0.0504 \\
(0.0476)\end{array}$ & $\begin{array}{c}0.0619 \\
(0.0477)\end{array}$ & $\begin{array}{c}0.0501 \\
(0.0477)\end{array}$ & $\begin{array}{c}0.0583 \\
(0.0475)\end{array}$ \\
\hline$r g r w$ & $\begin{array}{c}-0.172 * * * \\
(0.0655)\end{array}$ & $\begin{array}{c}-0.173 * * * \\
(0.0659)\end{array}$ & $\begin{array}{c}-0.173 * * * \\
(0.0658)\end{array}$ & $\begin{array}{l}-0.153 * * \\
(0.0646)\end{array}$ & $\begin{array}{l}-0.142 * * \\
(0.0644)\end{array}$ & $\begin{array}{l}-0.150 * * \\
(0.0647)\end{array}$ & $\begin{array}{l}-0.116^{*} \\
(0.0649)\end{array}$ \\
\hline rprod & $-0.242 * * *$ & $-0.252 * * *$ & $-0.248 * * *$ & $-0.228 * * *$ & $-0.232 * * *$ & $-0.234 * * *$ & $-0.237 * * *$ \\
\hline
\end{tabular}




\begin{tabular}{|c|c|c|c|c|c|c|c|}
\hline & $(0.0409)$ & $(0.0414)$ & $(0.0418)$ & $(0.0432)$ & $(0.0430)$ & $(0.0446)$ & $(0.0440)$ \\
\hline \multirow[t]{2}{*}{ ry } & $-0.177 * * *$ & $-0.181 * * *$ & $-0.180 * * *$ & $-0.140 * * *$ & $-0.133 * * *$ & $-0.144 * * *$ & $-0.141 * * *$ \\
\hline & $(0.0250)$ & $(0.0248)$ & $(0.0250)$ & $(0.0307)$ & $(0.0308)$ & $(0.0310)$ & $(0.0307)$ \\
\hline \multirow[t]{2}{*}{ ro } & $-0.226 * * *$ & $-0.244 * * *$ & $-0.234 * * *$ & $-0.139 *$ & -0.121 & $-0.149 *$ & $-0.141^{*}$ \\
\hline & $(0.0749)$ & $(0.0708)$ & $(0.0718)$ & $(0.0834)$ & $(0.0835)$ & $(0.0824)$ & $(0.0810)$ \\
\hline \multirow[t]{2}{*}{ rpopg } & $-4.112 * * *$ & $-4.441 * * *$ & $-4.167 * * *$ & $-4.400 * * *$ & $-4.004 * *$ & $-4.527 * * *$ & $-4.257 * * *$ \\
\hline & $(1.567)$ & $(1.408)$ & $(1.467)$ & (1.648) & $(1.656)$ & (1.598) & (1.599) \\
\hline \multirow[t]{2}{*}{ oilb } & $0.696 * * *$ & $0.695 * * *$ & $0.695 * * *$ & $0.719 * * *$ & $0.739 * * *$ & $0.719 * * *$ & $0.747 * * *$ \\
\hline & $(0.0375)$ & $(0.0377)$ & $(0.0380)$ & $(0.0390)$ & $(0.0405)$ & $(0.0395)$ & $(0.0406)$ \\
\hline \multirow[t]{2}{*}{ open } & $-0.118 * * *$ & $-0.116^{* * *}$ & $-0.115^{* * *}$ & $-0.105 * * *$ & $-0.103 * * *$ & $-0.102 * * *$ & $-0.101 * * *$ \\
\hline & $(0.0351)$ & $(0.0338)$ & $(0.0343)$ & $(0.0358)$ & $(0.0355)$ & $(0.0355)$ & $(0.0352)$ \\
\hline \multirow[t]{2}{*}{ fint } & $-0.0683 * * *$ & $-0.0679 * * *$ & $-0.0672 * * *$ & $-0.0675 * * *$ & $-0.0632 * * *$ & $-0.0668 * * *$ & $-0.0650 * * *$ \\
\hline & $(0.0142)$ & $(0.0142)$ & $(0.0142)$ & $(0.0142)$ & $(0.0143)$ & $(0.0142)$ & $(0.0143)$ \\
\hline \multirow[t]{2}{*}{ tot } & -0.0134 & -0.0137 & -0.0123 & -0.00801 & -0.000254 & -0.00737 & 0.00174 \\
\hline & $(0.0147)$ & $(0.0146)$ & $(0.0147)$ & $(0.0149)$ & $(0.0155)$ & $(0.0149)$ & $(0.0153)$ \\
\hline \multirow[t]{2}{*}{ constant } & $0.776 * * *$ & $0.807 * * *$ & $0.791 * * *$ & $0.677 * * *$ & $0.639 * * *$ & $0.692 * * *$ & $0.713 * * *$ \\
\hline & $(0.0903)$ & $(0.0908)$ & $(0.0915)$ & $(0.0984)$ & $(0.100)$ & $(0.102)$ & $(0.106)$ \\
\hline$o b s$ & 204 & 204 & 204 & 204 & 204 & 204 & 204 \\
\hline n. of ident & 12 & 12 & 12 & 12 & 12 & 12 & 12 \\
\hline
\end{tabular}

Standard errors in parentheses $* * * \mathrm{p}<0.01, * * \mathrm{p}<0.05, * \mathrm{p}<0.1$

Table A.5: Export concentration and uncertainty on the current account

\begin{tabular}{lrr}
\hline \hline Country & $\begin{array}{r}\text { Uncertainty on the } \\
\text { current account }\end{array}$ & $\begin{array}{r}\text { Export concentration } \\
\text { index }\end{array}$ \\
\hline Benin & 5.56 & 0.68 \\
Burkina Faso & 3.91 & 0.62 \\
Cameroon & $\mathbf{2 . 7 9}$ & $\mathbf{0 . 5 1}$ \\
Central African Republic & 3.99 & 0.58 \\
Chad & $\mathbf{1 5 . 7 6}$ & $\mathbf{0 . 8 0}$ \\
Republic of Congo & $\mathbf{1 5 . 3 3}$ & $\mathbf{0 . 7 7}$ \\
Ivory Coast & 9.26 & 0.57 \\
Gabon & $\mathbf{1 0 . 2 9}$ & $\mathbf{0 . 7 7}$ \\
Mali & 4.48 & 0.64 \\
Niger & 6.05 & 0.57 \\
Senegal & $\mathbf{2 . 7 8}$ & $\mathbf{0 . 4 4}$ \\
Togo & 5.85 & 0.50 \\
\hline Note: The uncertainty of the current account is apprehended by the current account \\
volatility measured by the standard deviation of the current account over the period \\
1980-2013. The export concentration indexes are those calculated from the ten top trade \\
partners. Normal bold indicates countries with high uncertainty, while italic bold \\
indicates countries with low uncertainty.
\end{tabular}




\section{Appendix B: Methodological details}

\section{B.1: Bayesian Model Averaging (BMA) methodology}

We use the BMA technique ${ }^{21}$ to shed light on the main fundamentals of the current account while considering the uncertainty associated with model specification given the relatively large number of potential determinants. The interest of this approach is that it tackles two major issues that typically arise in empirical studies with a relatively large number of explanatory variables and limited data, and for which classical regression models do not provide effective response, namely: (i) which variables should be included in the model? and (ii) what is their respective importance?

Let us consider the following empirical current account model:

$$
\mathrm{y}=\alpha_{\gamma}+X_{\gamma} \beta_{\gamma}+\epsilon \quad \epsilon \sim N\left(0, \sigma^{2} I\right)
$$

where $y$ is the current account, $X$ is a matrix of potential explanatory variables, $\alpha_{\gamma}$ is a constant, $\beta_{\gamma}$ denotes the coefficients, and $\epsilon$ is the error term.

BMA addresses the problem of uncertainty about model specification by estimating models for all possible combinations of $\{X\}$ and constructing a weighted average of all of them. Assuming that $X$ contains $K$ potential explanatory variables, this means estimating $2^{K}$ variable combinations and thus $2^{K}$ models, each with a certain probability of being the "true" model. If $\theta$ is the quantity of interest such as the coefficients $\beta$, the associated posterior distribution given data $D$ is:

$$
p(\theta \mid D)=\sum_{\gamma=1}^{2^{K}} p\left(\theta \mid M_{\gamma}, D\right) p\left(M_{\gamma} \mid D\right)
$$

Thus, the posterior distribution of $\theta$ is an average of the posterior distribution under each of the models considered, weighted by their posterior model probability. For a model $M_{\gamma}$, the latter are obtained using Bayes' theorem:

$$
p\left(M_{\gamma} \mid D\right)=\frac{p\left(D \mid M_{\gamma}\right) p\left(M_{\gamma}\right)}{\sum_{l=1}^{2^{K}} p\left(D \mid M_{l}\right) p\left(M_{l}\right)}
$$

where $p\left(D \mid M_{\gamma}\right)=\int p\left(D \mid \theta_{\gamma}, M_{\gamma}\right) p\left(\theta_{\gamma} \mid M_{\gamma}\right) d \theta_{\gamma}$ is the integrated likelihood of model $M_{\gamma}, \theta_{\gamma}$ is the vector of parameters of model $M_{\gamma}, p\left(\theta_{\gamma} \mid M_{\gamma}\right)$ is the prior density of $\theta_{\gamma}$ under model $M_{\gamma}$, $p\left(D \mid \theta_{\gamma}, M_{\gamma}\right)$ is the likelihood and $p\left(M_{\gamma}\right)$ is the prior probability that $M_{\gamma}$ is the true model. The latter has to be elicited by the researcher and should reflect prior beliefs. As Fernandez et al. (2001), we choose a uniform prior probability, i.e. $p\left(M_{\gamma}\right)=2^{-K}$. This is a popular choice to represent the lack of prior knowledge.

Following Hoeting et al. (1999), the posterior mean and variance of $\theta$ are respectively given by:

\footnotetext{
${ }^{21}$ This technique is briefly presented in this paper. For more technical details, we refer the reader to some key references such as Hoeting et al. (1997), Hoeting et al. (1999) and Fernandez et al. (2001).
} 


$$
\begin{aligned}
& E(\theta \mid D)=\sum_{\gamma=0}^{2^{K}} \widehat{\Delta}_{\gamma} p\left(M_{\gamma} \mid D\right), \\
& V(\theta \mid D)=\sum_{\gamma=0}^{2^{K}}\left(V\left(\theta \mid D, M_{\gamma}\right)+\widehat{\Delta}_{\gamma}^{2}\right) p\left(M_{\gamma} \mid D\right)-E(\theta \mid D)^{2},
\end{aligned}
$$

where $\hat{\Delta}_{\gamma}=E\left(\theta \mid D, M_{\gamma}\right)$.

\section{B.2: Calculation of export concentration index}

This index is obtained from the CUNCED database. The latter calculates the index on the basis of detailed information on bilateral trade between countries. Products considered in the calculation are those whose value is at least $\$ 100000$ US or more than $0.3 \%$ of exports from countries or groups of countries towards / from specified commercial partners. The concentration index is also known as the Herfindahl-Hirschman index. It is normally calculated for all trading partners, but it can be broken down by specific trading partners for the purpose of further analysis. It has been normalized to obtain values between 0 and 1 (maximum concentration) and is calculated from the following formula:

$$
H_{j k}=\frac{\sqrt{\sum_{i=1}^{n}\left(\frac{x_{i j k}}{\sum_{i=1}^{n} x_{i j k}}\right)^{2}}-\sqrt{1 / n}}{1-\sqrt{1 / n}}
$$

where $H_{j k}$ is the index of export concentration of the country or group of countries $j$ towards the partner or group of partner countries $k . x_{i j k}$ represent exports of product $i$ from country $j$ toward the partner $k . n$ is the number of products. The higher the index is to 1 , the higher is the level of export concentration. Conversely, an index close to 0 shows a broad diversification of exports. 


\section{Appendix C: Graphs}

\section{Figure C.1: Posterior Coefficient Densities (fundamentals)}

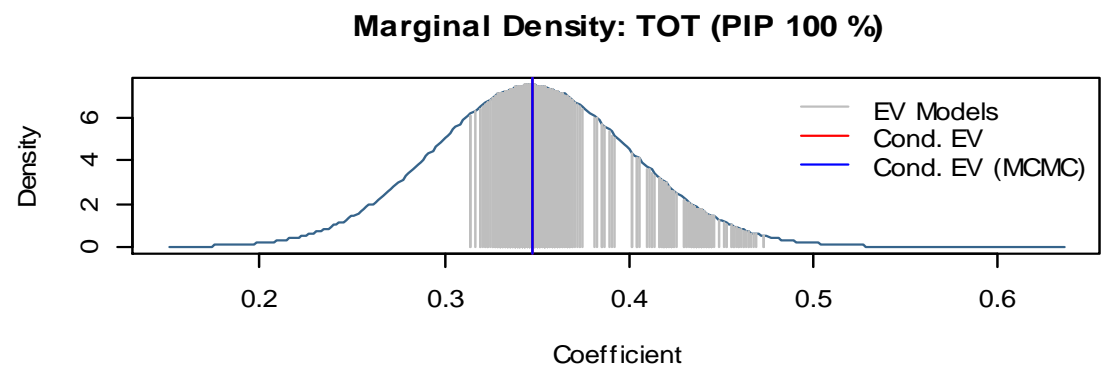

Marginal Density: PROD (PIP $98.71 \%$ )

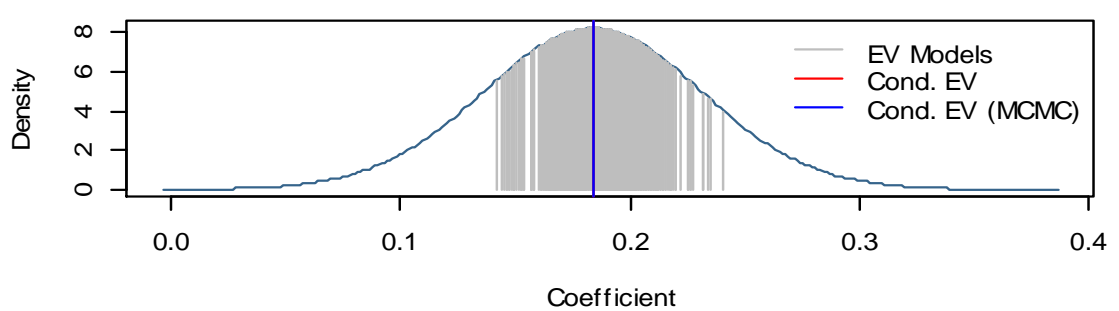

Marginal Density: GOV (PIP $87.07 \%)$

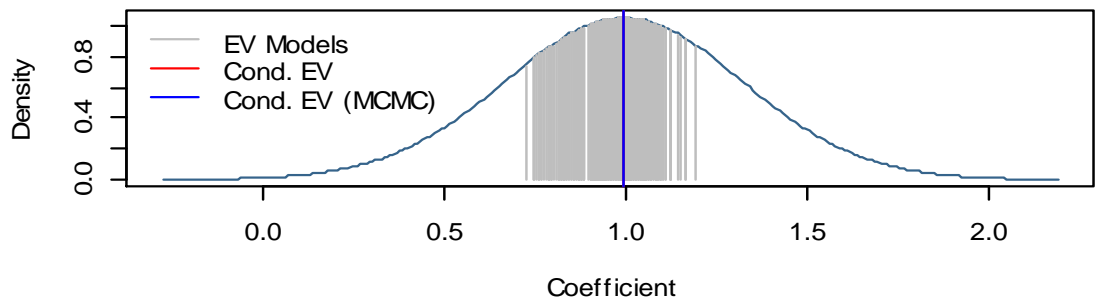

Note: The coefficients represented here are those obtained from 4-year averaged data. "EV" denotes expected value, "Cond. EV" refers to the expected coefficient based on analytical posterior model probabilities and "Cond. EV (MCMC)" denotes the expected conditional coefficient from MCMC. "Cond. EV" and "Cond. EV (MCMC)" coincide in most cases. 
Graph C.2: Overvaluation (\%) and current account (CA, \% of GDP)

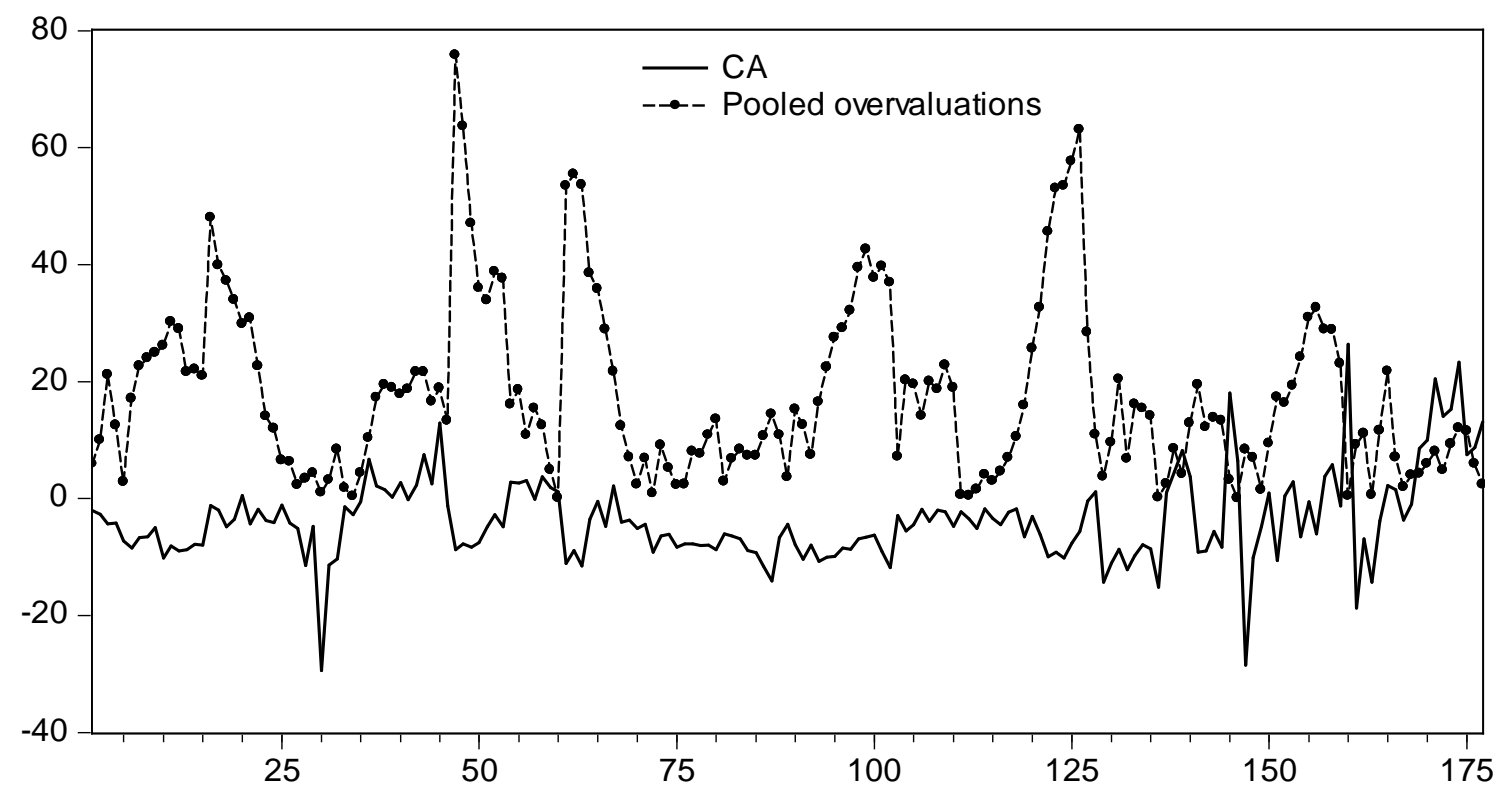

Graph C.3: Undervaluation (\%) and current account (CA, \% of GDP)

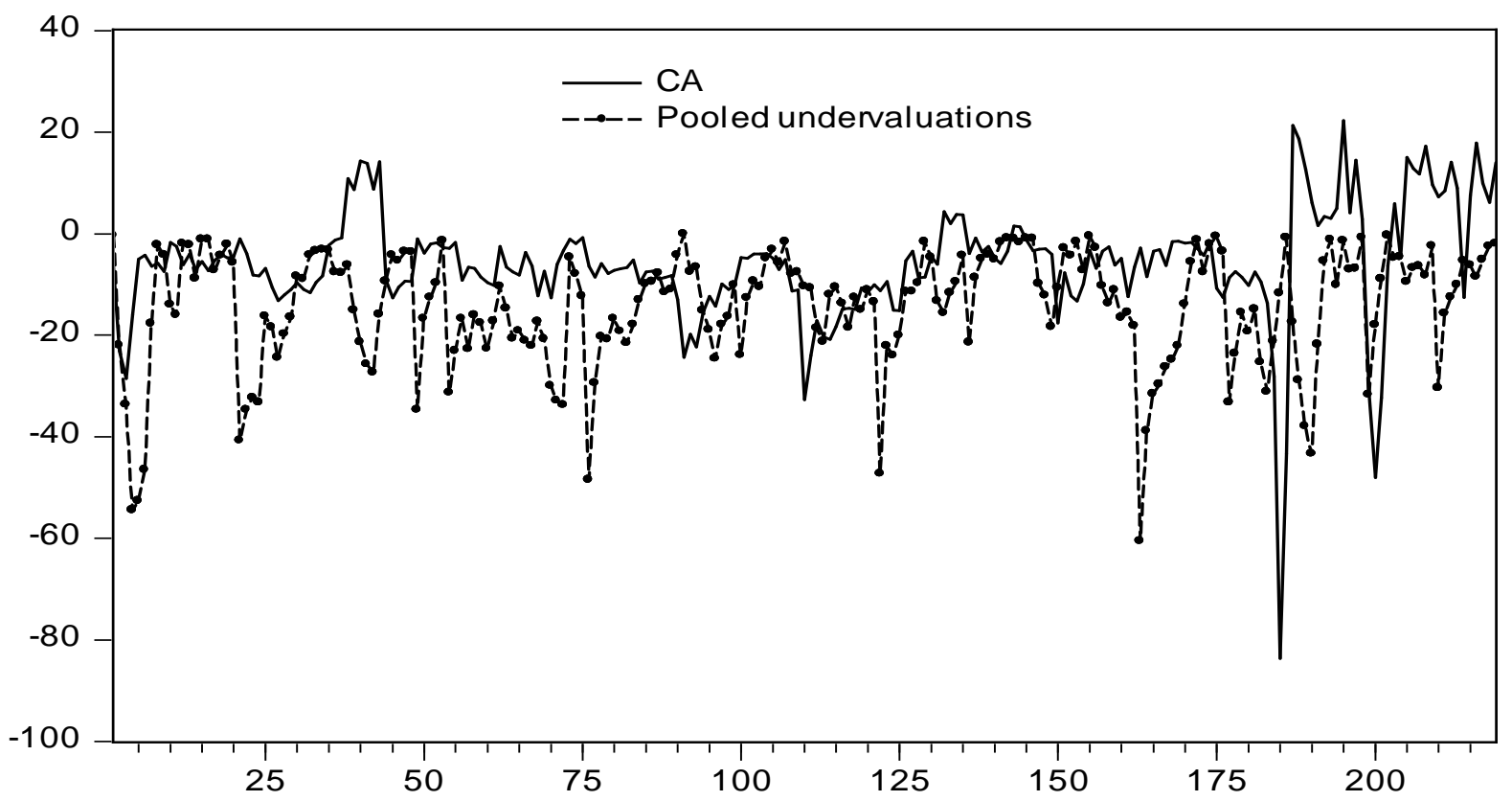

